\title{
Marine sponges as a powerful tool for trace elements biomonitoring studies in coastal environment
}

\author{
Anna Maria Orani $^{\mathrm{a}, \mathrm{b}, *}$, Aurélie Barats ${ }^{\mathrm{a}}$, Emilia Vassileva ${ }^{\mathrm{b}}$, Olivier P. Thomas ${ }^{\mathrm{c}}$ \\ ${ }^{\text {a } U n i v e r s i t e ́ ~ N i c e ~ S o p h i a ~ A n t i p o l i s, ~ C N R S, ~ I R D, ~ O b s e r v a t o i r e ~ d e ~ l a ~ C o ̂ t e ~ d ' A z u r, ~ G e ́ o a z u r, ~ U M R ~ 7329, ~} 250$ rue Albert Einstein, Sophia Antipolis, 06560, Valbonne, France \\ ${ }^{\mathrm{b}}$ International Atomic Energy Agency, Environment Laboratories, 4 Quai Antoine 1er, 98000, Monaco, Principality of Monaco \\ ${ }^{\mathrm{c}}$ Marine Biodiscovery, School of Chemistry and Ryan Institute, National University of Ireland Galway (NUI Galway), University Road, H91 TK33 Galway, Ireland
}

In this work, we performed a comparative study on six marine sponge species collected along the French Mediterranean and Irish coasts for their TEs accumulation. Intra and inter-species variabilities were examined. Among the Mediterranean species, Cymbaxinella damicornis accumulates significantly more As and $\mathrm{Cu}$ than others sponge species; Chondrilla nucula more Ni and Mo and Acanthella acuta more Ag. Among Irish samples, Hymeniacidon perlevis showed higher accumulation properties for most of TEs in comparison to Halichondria panicea. Bioconcentration Factors were $>1$ in all species for most of TEs. This study suggests that TEs bioaccumulation is most likely associated to differences in morphological features and/or to specific bacterial communities associated to different species. The determination of $\mathrm{Pb}$ isotope ratios revealed mainly natural $\mathrm{Pb}$ sources for Mediterranean and Kilkieran Bay's samples, and rather anthropogenic influence for Belfast samples. This study confirms that sponges represent a powerful tool for biomonitoring studies.

\section{Introduction}

The occurrence of trace elements (TEs) in aquatic environments is related to natural sources, but also to anthropogenic inputs from industrial activities. TE contaminations in the marine environment occur worldwide and the assessment of the pollution status is required, leading to the publication of several studies on this subject (Li et al., 2000; Caccia et al., 2003; Fang et al., 2014; Parra et al., 2015; Cabrita et al., 2017; Ashraf et al., 2017). Environmental surveys are often performed on water samples but, in marine ecosystems, the very low TEs concentrations and the high salinity of seawater cause severe limitations in the measurements (Søndergaard et al., 2015). Monitoring studies on TEs contamination are often focused on sediments and biota. Indeed, sediments act as sink and reservoirs of contaminants thus displaying higher TEs contents and not presenting problems related to short residence time such as for water (Varol, 2011; Liu et al., 2015). Marine organisms find also application as tools for characterizing the state of a marine ecosystem as some of them are recognized to accumulate TEs. They represent a good alternative especially in rocky shores where sediments are not easily found. Sessile and active filter feeding invertebrates are often used to determine temporal and spatial variation of TE in aquatic systems (Weis and Weis, 1999; Denton et al., 2006; Dahms et al., 2014). An ideal biomonitor should be a natural accumulator of the element of interest and possibly with high concentration factor, in order to highlight possible difference between times or sites (Rainbow, 2002).

Historically, bivalves are considered as ideal biomonitor organisms as exemplified by the "mussel watch program" (Cantillo, 1998) also for their importance as widespread consumed seafood. More recently, sponges gained attention as possible biomonitors of TEs contamination as they are widespread, abundant in some ecosystems, long-living, easily sampled, sessile filter-feeders and highly tolerant to several pollutants (de Mestre et al., 2012; Batista et al., 2014). Additionally, sponge communities can remain stable for long periods, making them suitable model organisms for monitoring studies. Sponges pump large quantities of seawater (100-1200 $\left.\mathrm{mL} \mathrm{h}^{-1} \mathrm{~g}^{-1}\right)$, more than any other marine invertebrates (Olesen and Weeks, 1994). These organisms have a high capacity for TEs accumulation (Patel et al., 1985; Padovan et al., 2012), exhibiting higher filtering capacity than bivalves (Negri et al., 2006; Gentric et al., 2016). They are considered as "biological particle traps" due to their ability to concentrate a wide range of chemicals from both the suspended and dissolved phases of the water, with usually high bioconcentration factors (BCF) (Perez et al., 2005; Cebrian et al., 2003). The detection of large quantities of TEs in sponges suggests either a high tolerance to diverse type of chemicals or the existence of detoxification systems (Aly et al., 2013). These characteristics make them

\footnotetext{
* Corresponding author at: International Atomic Energy Agency, Environment Laboratories, 4 Quai Antoine 1er, 98000 Monaco, Principality of Monaco

E-mail address: a.m.orani@iaea.org (A.M. Orani).
} 
suitable as a model organisms applied in TEs monitoring projects, and their use has been proposed in several studies (Negri et al., 2006; Venkateswara Rao et al., 2009; Illuminati et al., 2016). Sponges have also been reported as efficient environmental bioremediators of different chemicals or even microbes such as the organochlorine pesticide lindane (Aresta et al., 2015) and the bacterium Escherichia coli (Milanese et al., 2003). These characteristics, combined with a demonstrated interest for sponges as a source of novel pharmaceuticals (Anjum et al., 2016), open the way for self-financing sponge remediation programs (Gifford et al., 2007).

The main objective of this work was the assessment of TEs pollution in several sponge species of different morphologies and collected in different areas. A comparative study on TEs bioaccumulation was performed on six sponge species collected on the Southern French Mediterranean coast and in Ireland. These areas have been selected because of their differences in terms of TEs biogeochemical background and anthropogenic inputs. The bioaccumulation potential of these sponges was examined for a broad range of TEs, comparing with values measured in sediment samples collected in the same area. Additionally, measurements of $\mathrm{Pb}$ isotope ratios were performed for the first time in sponges and allowed us to give insights on the principal sources of $\mathrm{Pb}$ contamination in the studied zones.

\section{Materials and methods}

\subsection{Sampling}

Sponge and sediment samples were collected in three sampling sites: the Mediterranean coast, in the Grotte du Lido at Villefranche sur Mer, France ( $\mathrm{N} 43^{\circ} 41^{\prime} 59.0^{\prime \prime}$, E $07^{\circ} 19^{\prime} 31.5^{\prime \prime}$ ) and two coastal sites in Ireland, Greenisland in the Belfast Lough (N54 $41^{\prime} 24.383^{\prime \prime}$, O $5^{\circ} 51^{\prime}$ $\left.36.633^{\prime \prime}\right)$ and Kilkieran Bay (N 53 $21^{\prime} 22.625^{\prime \prime}$, O $9^{\circ} 42^{\prime} 17.153^{\prime \prime}$ ) in Galway county (Fig. 1). Sediment samples were collected during each sampling session, using an acid pre-cleaned polyethylene tube. Sponges were collected using a plastic knife and placed in separate plastic bag. Different sponge species were sampled: Acanthella acuta, Cymbaxinella

a)

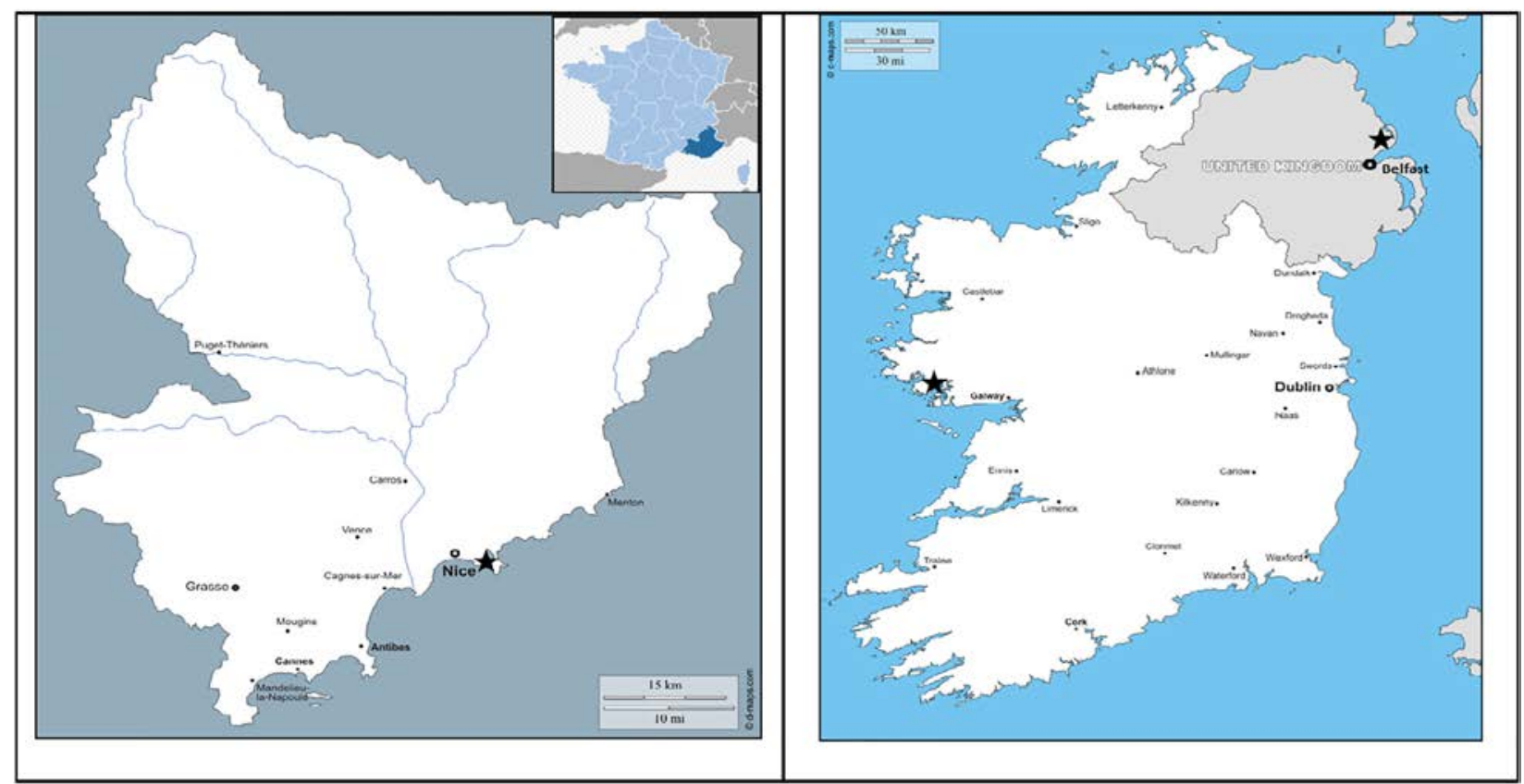

damicornis, Chondrilla nucula and Haliclona fulva in the Mediterranean coast; Halichondria panicea and Hymeniacidon perlevis in Ireland. A list of samples with details on morphology and known bacterial associated population is presented in Table 1 . These sponge species were described in details in a recently published paper (Orani et al., 2018). At least three specimens of similar size were randomly selected for each sponge species and during each sampling. Sediments and four species of Mediterranean sponges were collected by SCUBA diving at $20 \mathrm{~m}$ depth on February and September 2016 (winter and summer). During the first sampling, three specimens of $C$. damicornis were collected deeper in the cave while the remaining two specimens were from the entrance. During the second sampling, three specimens of $C$. nucula were collected at $5 \mathrm{~m}$ depth while three other specimens at $20 \mathrm{~m}$. In Ireland, sediments and sponges were hand-sampled in intertidal zones. Samples from Kilkieran Bay and from Belfast were collected in September 2016 and in October 2016, respectively.

\subsection{Sample preparation}

All solutions were prepared with double deionized water obtained from Millipore water purification system (Elix \& Synergy) (resistivity of $18.2 \mathrm{M} \Omega \mathrm{cm}^{-1}$, Total Organic Carbon $<5 \mu \mathrm{g} \mathrm{L}^{-1}$ and microorganisms $<0.1 \mathrm{UFC} \mathrm{mL}^{-1}$ ). All PTFE and Teflon containers used for sample preparation and analyses were pre-cleaned using a procedure consisting of $24 \mathrm{~h}$ bath in $10 \% \mathrm{HNO}_{3}$ (prepared from proper dilution of $65 \%$ analytical grade $\mathrm{HNO}_{3}$, Fisher Chemicals) and careful rinsing three times with Milli-Q water. Sediment and sponge samples were freeze-dried, ground in agate mortar, and kept in closed PTFE tubes placed in a desiccator.

For trace elements analysis by ICP-MS, a microwave digestion was carried out into a closed microwave system (Ethos One, Milestone). Teflon reactors were filled with an aliquot of about $50 \mathrm{mg}$ of sponge sample (or $100 \mathrm{mg}$ of bulk sediment sample), with $5 \mathrm{~mL}$ of $\mathrm{HNO}_{3}$ (Trace Metal Grade, 67 to $70 \% w / w$, Fisher Chemical) and $2 \mathrm{~mL}$ of HF (Ultra Trace Elemental Analysis $47-51 \% \mathrm{w} / \mathrm{w}$, Optima, Fisher Chemical). Temperature program used for acid digestion consisted of a 20-min b)

Fig. 1. Maps showing the sampling sites (indicated with black stars) located a) in the French Mediterranean coast (http://d-maps.com/carte.php?num_car $=110470 \&$ lang $=e n)$ and b) in two locations along the Irish coast (http://d-maps.com/carte.php?num_car=14642\&lang=en). Copyright d-maps.com 
Table 1

List of specimens collected and analyzed in the present study with details on different morphological characteristics and microbial abundances. LMA stands for Low Microbial Abundance and HMA for High Microbial Abundance (Vacelet and Donadey, 1977).

\begin{tabular}{|c|c|c|c|c|c|c|}
\hline Sponge specie & Shape & Skeleton & Microbial abundance & Number of specimens & Code & Sampling site \\
\hline Acanthella acuta & Branch erected & Spongin and dense spicules & LMA & 6 & AC.A & Villefranche-sur-Mer \\
\hline Cymbaxinella damicornis & Branch erected & Spicules & LMA & 7 & CY.D & Villefranche-sur-Mer \\
\hline Haliclona fulva & Thick encrusting & Spicules & LMA & 6 & HA.F & Villefranche-sur-Mer \\
\hline Chondrilla nucula & Thick encrusting & Dense collagen and spicules & HMA (cyanobacteria) & 9 & $\mathrm{CH} \cdot \mathrm{N}$ & Villefranche-sur-Mer \\
\hline \multirow[t]{2}{*}{ Halichondria panicea } & Massive & Dense spicules, scarce spongin & LMA & 4 & HA.P & Kilkieran Bay \\
\hline & & & & 6 & HA.P Bel & Belfast Lough \\
\hline \multirow[t]{2}{*}{ Hymeniacidon perlevis } & Thick encrusting & Spicules, scarce spongin & HMA (cyanobacteria) & 3 & $\mathrm{HY} \cdot \mathrm{P}$ & Kilkieran Bay \\
\hline & & & & 7 & HY·P Bel & Belfast Lough \\
\hline
\end{tabular}

Table 2

Comparison of measured concentrations and certified values in 2 CRMs: TORT2 (lobster hepatopancreas) and MESS-2 (estuarine sediments).

\begin{tabular}{|c|c|c|c|c|c|}
\hline & & $\begin{array}{l}\text { Measured } \\
\text { value } \\
\left(\mathrm{mg} \mathrm{kg}^{-1}\right)\end{array}$ & $\begin{array}{l}\text { Relative } \\
\text { Standard } \\
\text { Deviation } \\
(\%)\end{array}$ & Recovery (\%) & $\begin{array}{l}\text { Certified } \\
\text { value } \\
\left(\mathrm{mg} \mathrm{kg}^{-1}\right)\end{array}$ \\
\hline \multirow{10}{*}{$\begin{array}{l}\text { TORT-2 } \\
\qquad \begin{array}{l}(n=1- \\
0)\end{array}\end{array}$} & $\mathrm{V}$ & $2.2 \pm 0.56$ & 25 & 135 & $1.64 \pm 0.15$ \\
\hline & $\mathrm{Ni}$ & $2.7 \pm 0.7$ & 25 & 106 & $2.5 \pm 0.19$ \\
\hline & $\mathrm{Cu}$ & $97 \pm 6$ & 6 & 91 & $106 \pm 10$ \\
\hline & $\mathrm{Zn}$ & $205 \pm 36$ & 17 & 114 & $180 \pm 6$ \\
\hline & As & $19.8 \pm 3.5$ & 18 & 92 & $21.6 \pm 1.8$ \\
\hline & Mo & $0.94 \pm 0.21$ & 22 & 99 & $0.95 \pm 0.1$ \\
\hline & $\mathrm{Ag}$ & $6.1 \pm 0.4$ & 6 & & \\
\hline & $\mathrm{Cd}$ & $25.7 \pm 1.7$ & 6 & 96 & $26.7 \pm 0.6$ \\
\hline & $\mathrm{Ba}$ & $2.6 \pm 0.8$ & 30 & & \\
\hline & $\mathrm{Pb}$ & $0.35 \pm 0.20$ & 57 & 100 & $0.35 \pm 0.13$ \\
\hline \multirow{8}{*}{$\begin{array}{l}\text { MESS- } 2 \\
\quad(n=4)\end{array}$} & $\mathrm{V}$ & $234 \pm 15$ & 6 & 93 & $252 \pm 10$ \\
\hline & $\mathrm{Ni}$ & $46 \pm 2$ & 4 & 94 & $49.3 \pm 1.4$ \\
\hline & $\mathrm{Cu}$ & $37 \pm 3$ & 8 & 95 & $39.3 \pm 2.0$ \\
\hline & $\mathrm{Zn}$ & $155 \pm 12$ & 8 & 90 & $172 \pm 16$ \\
\hline & As & $19 \pm 1$ & 8 & 92 & $20.7 \pm 0.8$ \\
\hline & Mo & $2.9 \pm 0.8$ & 27 & 101 & $2.85 \pm 0.12$ \\
\hline & $\mathrm{Ba}$ & $794 \pm 183$ & 23 & & \\
\hline & $\mathrm{Pb}$ & $20 \pm 4$ & 23 & 91 & $21.9 \pm 1.2$ \\
\hline
\end{tabular}

ramp temperature up to $180{ }^{\circ} \mathrm{C}$, followed by an isothermal phase of $30 \mathrm{~min}$. The mineralized solutions were then transferred to polyethylene pre-cleaned tubes and gravimetrically diluted with Milli-Q water, up to a final weight of about $50 \mathrm{~g}$. These solutions were further diluted 15 times in Milli-Q water prior to ICP-MS analyses. The same sample preparation and analyses were performed on two Certified Reference Materials (CRMs) to ensure quality control of the entire analytical procedure. The used materials were TORT-2 (Lobster hepatopancreas, NRC, Canada) and MESS-2 (Estuarine sediment, NRC, Canada); 50 and $100 \mathrm{mg}$ of these CRMs were used respectively. At least, one procedural blank and one CRM were included in each digestion run and analyzed with the rest of the samples. A summary of results obtained for CRMs analyzed in this study is presented in Table 2; and in all cases a good agreement with certified values was found. $\mathrm{Cd}$ and $\mathrm{Ag}$ in MESS-2 were below the limits of quantification, therefore they are not listed in the table with other analytes.

One specimen of each sponge species and one sediment sample for each location were selected for $\mathrm{Pb}$ isotope ratios analysis. An aliquot of about $100 \mathrm{mg}$ of sponge or sediment sample was decomposed in $5 \mathrm{~mL}$ ultrapure $\mathrm{HNO}_{3}$ (Fisher scientific, Hampton, USA) and $2 \mathrm{~mL}$ of ultrapure HF (Fisher scientific, Hampton, USA) using the Mars X-press Microwave (CEM Mars X-press) equipped with a 12 vessels carousel. After the digestion, the solutions were placed on a ceramic heating plate, under laminar hood, and concentrated to near dryness. The residues were taken up in $2 \% \mathrm{HNO}_{3}$, transferred to $50 \mathrm{~mL} \mathrm{PE}$ tubes and stored at $4{ }^{\circ} \mathrm{C}$. Solutions for $\mathrm{Pb}$ isotope ratios determination were diluted (at least 50 times) with $2 \% \mathrm{HNO}_{3}$ in class 100 clean room.
Table 3

(Q) ICP-MS settings used for the determination of trace metals in sediments and sponges and limits of detection.

\begin{tabular}{|c|c|c|c|c|}
\hline \multicolumn{3}{|l|}{ Parameter } & \multicolumn{2}{|l|}{ Value } \\
\hline \multicolumn{3}{|l|}{ RF power } & \multicolumn{2}{|l|}{$1550 \mathrm{~W}$} \\
\hline \multicolumn{3}{|c|}{ Plasma gas flow } & \multicolumn{2}{|l|}{$15 \mathrm{Lmin}^{-1}$} \\
\hline \multicolumn{3}{|c|}{ Auxiliary gas flow } & \multicolumn{2}{|l|}{$1.1 \mathrm{~mL} \mathrm{~min}^{-1}$} \\
\hline \multicolumn{3}{|c|}{ Carrier gas flow } & \multicolumn{2}{|l|}{$0.9 \mathrm{Lmin}^{-1}$} \\
\hline \multicolumn{3}{|c|}{ Nebulizer } & \multicolumn{2}{|c|}{ Quartz concentric } \\
\hline \multicolumn{3}{|c|}{ Spray chamber } & \multicolumn{2}{|l|}{ Cyclonic } \\
\hline \multicolumn{3}{|l|}{ Interface } & \multicolumn{2}{|c|}{ Pt sampling and skimmer cones } \\
\hline \multicolumn{3}{|c|}{ Oxide formation ${ }^{140} \mathrm{Ce}^{16} \mathrm{O}^{+} /{ }^{140} \mathrm{Ce}^{+}$} & \multicolumn{2}{|c|}{$<3 \%$} \\
\hline \multicolumn{3}{|c|}{ Double charged species } & \multicolumn{2}{|l|}{$<2 \%$} \\
\hline \multicolumn{3}{|c|}{ Measured isotopes } & \multirow{2}{*}{\multicolumn{2}{|c|}{$\begin{array}{l}{ }^{51} \mathrm{~V},{ }^{60} \mathrm{Ni},{ }^{63} \mathrm{Cu},{ }^{66} \mathrm{Zn},{ }^{75} \mathrm{As},{ }^{98} \mathrm{Mo} \\
{ }^{107} \mathrm{Ag},{ }^{111} \mathrm{Cd},{ }^{138} \mathrm{Ba},{ }^{208} \mathrm{~Pb} \\
{ }^{40} \mathrm{Ar}{ }^{37} \mathrm{Cl},{ }^{82} \mathrm{Se},{ }^{95} \mathrm{Mo}^{16} \mathrm{O},{ }^{37} \mathrm{Cl}^{16} \mathrm{O}\end{array}$}} \\
\hline \multicolumn{3}{|c|}{ Mass for interference assessment } & & \\
\hline \multicolumn{5}{|c|}{ Limits of detection $\left(\mu \mathrm{g} \mathrm{L}^{-1}\right)$} \\
\hline $\mathrm{V}=0.02$ & $\mathrm{Zn}=0.3$ & As $=0.03$ & $\mathrm{Ag}=0.002$ & $\mathrm{Ba}=0.006$ \\
\hline $\mathrm{Ni}=0.03$ & $\mathrm{Cu}=0.008$ & Mo $=0.002$ & $\mathrm{Cd}=0.007$ & $\mathrm{~Pb}=0.002$ \\
\hline
\end{tabular}

\subsection{Analyses and data treatments}

A quadrupole Inductively Coupled Plasma Mass Spectrometer ((Q) ICP-MS; Elan DRCII, Perkin Elmer) was used for the determination of $\mathrm{Ag}, \mathrm{As}, \mathrm{Cd}, \mathrm{Cu}, \mathrm{Mo}, \mathrm{Ni}, \mathrm{Pb}, \mathrm{Ba}$ and $\mathrm{Zn}$ in sponge and sediment samples. ICP-MS operating parameters are summarized in Table 3. Analytes quantification was performed by means of external calibration, using daily prepared standards obtained by proper dilution of multi-elemental standard for ICP-MS (ICP-MS standard $\mathrm{N}^{\circ} 3$ Perkin Elmer ${ }^{\circledR}$ and ICPMS standard $\mathrm{N}^{\circ} 2$ from SCP SCIENCE ${ }^{\circledR}$ ). An internal standard solution, containing 10 and $1 \mu \mathrm{g} \mathrm{L}{ }^{-1}$ of $\mathrm{Ge}$ and $\mathrm{Tb}$ respectively, was prepared by dilution of mono-elemental standards of Ge and $\mathrm{Tb}$ (PlasmaCal, SCP SCIENCE ${ }^{\circledR}$ ) and used during the ICP-MS analysis to correct for possible matrix effects. Daily analyses of the certified reference natural river water SLRS-5 or SLRS-6 (National Research Council, Canada) were carried out to check measurement accuracy (Barats et al., 2014). All results were corrected for instrumental blanks. The ongoing instrument performance was monitored with the repeated analysis of standards. Detection limits for analytes are also reported in Table 3.

Determination of $\mathrm{Pb}$ isotope ratios was carried out by means of High Resolution Sector Field (HR-SF) ICP-MS (NuAttom, NuInstruments Ltd., Wrexham, UK). The Standard Reference Material SRM 981 from the National Institute of Standards and Technology (NIST, USA) with certified $\mathrm{Pb}$ isotopic composition was used for correction of the instrumental mass discrimination. The bracketing approach based on linear law was used for correction (Vanhaecke et al., 2009). The instrument parameters for $\mathrm{Pb}$ isotopic ratios measurements with (HR-SF) ICP-MS are presented in Table 4. The ${ }^{204} \mathrm{Hg}$ isobaric interference on ${ }^{204} \mathrm{~Pb}$ isotope was corrected by monitoring the mass ${ }^{202} \mathrm{Hg}$ and applying a correction equation based on natural abundancy of isotopes ${ }^{202} \mathrm{Hg}$, ${ }^{204} \mathrm{Hg}$ and ${ }^{204} \mathrm{~Pb}$. 
Table 4

(HR-SF) ICP-MS parameters optimized for the determination of $\mathrm{Pb}$ isotope ratios in sponges and sediment samples.

\begin{tabular}{ll}
\hline Parameter & Value \\
\hline Coolant gas flow & $13.5 \mathrm{~L} \mathrm{~min}^{-1}$ \\
Auxiliary gas flow & $0.8 \mathrm{~L} \mathrm{~min}^{-1}$ \\
Nebulizer gas flow & $29.6 \mathrm{psi}$ \\
Plasma power & $1300 \mathrm{~W}$ \\
Sensitivity for $1 \mathrm{ng} \mathrm{g}{ }^{-1}\left({ }^{208} \mathrm{~Pb}\right)$ & $>800,000 \mathrm{cps}$ \\
Background on mass 220 & $<2 \mathrm{cps}$ \\
Acquisition Mode & Peak Jumping \\
Number of sweeps & 500 \\
Number of cycles & 25 \\
Dwell time per isotope $(\mathrm{ms})$ & 1000 \\
Measured isotopes & $202 \mathrm{Hg},{ }^{204} \mathrm{~Pb},{ }^{206} \mathrm{~Pb},{ }^{207} \mathrm{~Pb},{ }^{208} \mathrm{~Pb}$ \\
Mass resolution & 300 \\
Oxide Formation ${ }^{140} \mathrm{Ce}^{16} \mathrm{O}^{+} /{ }^{140} \mathrm{Ce}$ & $<1 \%$ \\
\hline
\end{tabular}

Statistical data treatments were performed using XLSTAT (version 2014.05.5, Addinsoft, Paris, France). Principal component analysis (PCA) was applied to TEs concentrations measured in sponges in order to highlight common trends between different species. Data were standardized using the biased standard deviation, to avoid biases due to differences in data dimensionality. Lead was not included in the PCA due to its high intra-species variability and it will be treated in a separated paragraph.

\subsection{The use of lead isotope ratios}

Lead isotope ratios measurement represents a very powerful analytical tool applied to several fields of study. $\mathrm{Pb}$ has a partially-radiogenic isotopic composition, since three of its stable isotopes $\left({ }^{206} \mathrm{~Pb}\right.$, ${ }^{207} \mathrm{~Pb}$ and ${ }^{208} \mathrm{~Pb}$ ) are the final product of the radioactive decay of ${ }^{235} \mathrm{U}$, ${ }^{232} \mathrm{Th}$ and ${ }^{238} \mathrm{U}$ respectively (Vanhaecke and Degryse, 2012). ${ }^{204} \mathrm{~Pb}$ is the only natural isotope and its abundance has remained constant since the formation of the solar system (Komárek et al., 2008). Thanks to this characteristic, $\mathrm{Pb}$ isotope composition is governed by the original composition of the parent isotopes, and thus is typical and characteristic of a given area/sample. $\mathrm{Pb}$ isotope ratios are a powerful tool often used for provenance studies in several fields, such as forensic science and cultural heritage investigations (Sjåstad et al., 2011; Drivelos and Georgiou, 2012; Ortega et al., 2012). The application of Pb isotope ratios measurement in environmental science is of great interest since it allows to distinguish between different $\mathrm{Pb}$ sources, whether they are natural or anthropogenic (Hinrichs et al., 2002; Larsen et al., 2012).

\section{Results and discussion}

\subsection{TEs concentrations in sponges}

Average TEs concentrations according to sampling site, date and sponge species are summarized in Tables $1 \mathrm{~S}$ and 2S (supplementary information). Accounting for the intra-species variability, it was possible to evaluate the differences in TEs bioaccumulation for different sampling conditions (depth, light, and seasons) or between different species of the same sampling site. Additionally, two species $H$. panicea and $H$. perlevis were collected in two different sampling sites around Ireland, making possible a direct comparison of these species bioaccumulation trends with respect to TEs availability in the surrounding environment.

\subsubsection{Intra-species variability}

The variability of TEs bioaccumulation within a same sponge species can be evaluated with the relative standard deviation (RSD\%) calculated from different specimens of the same sponge species. In Mediterranean sponges, a variability of TEs concentrations was noticed depending on the target TE and sponge species, with an average RSD of $30 \%$. Among TEs, Mo, As, Cd and $\mathrm{Cu}$ showed the lowest variabilities (averaging 21, 15, 16, 17 and $21 \%$, respectively). The intra-species variability can also be very low for some sponge species e.g. for Ba in $C$. damicornis (1\%) or for As in C. nucula. at $20 \mathrm{~m}$ depth (3\%) during the second sampling. The average RSD values for $\mathrm{V}, \mathrm{Ni}, \mathrm{Zn}, \mathrm{Ag}$ and $\mathrm{Ba}$ was $33 \%$. For all species collected in the Mediterranean sites, $\mathrm{Pb}$ showed by far the highest intra-specific variability, showing an average RSD of $69 \%$ and reaching values up to $121 \%$ (e.g. for $H$. fulva for the second sampling).

In Irish sponges, the intra-specific variability ranges from 2 to $55 \%$ for all TEs (even for $\mathrm{Pb}$ ), with average around 33\%, such as in Mediterranean samples. The maximum RSD value found for Irish samples is $55 \%$ for Ba measured in $H$. panicea from Kilkieran Bay. Arsenic showed the lowest intra-species variability for $H$. panicea from Belfast (14\%) and for H. perlevis from Kilkieran (8\%). Mo and Zn presented the lowest RSD values in $H$. panicea from Kilkieran $(2 \%)$ and $H$. perlevis from Belfast (7\%), respectively. $\mathrm{Pb}$ did not show the same behavior as in the Mediterranean samples, since its intra-specific variability for all studied species was similar to values obtained for other TE.

In this study, the natural variability within the same sponge species seems to be dependent both on the considered analyte and the sponge species itself. The factor most likely governing this intra-specific variability can be related to possible differences in organism age. Besides, it seems that some elements like $\mathrm{Pb}$ are more affected by this natural internal variability than other TE such as Cd, Mo, and V. For the Atlantic and Mediterranean sponge samples, the natural intra-specific variability observed in this study had average values around $30-33 \%$, which agrees with literature data on TEs in sponges. Müller et al. (1998) reported RSD up to 33\% for Cd and Cu in Suberites domuncula. Perez et al. (2005) showed RSD up to $70 \%$ and $50 \%$ for $\mathrm{Mn}$ and $\mathrm{Pb}$ in Spongia officinalis, respectively. These previous results are in the same range of RSD found for $\mathrm{Pb}$ in Mediterranean sponges analyzed in the present study. A natural variability has thus to be expected, even for samples analyzed in pristine environment such as the Antarctic (Grotti et al., 2008). This natural variability is not always taken into consideration in biomonitoring studies and should be considered when interpreting results.

\subsubsection{Influence of sampling site on the TE concentrations in Mediterranean sponges}

During the same sampling date, specimens of $C$. damicornis and $C$. nucula were collected at different depths and light conditions to evaluate the influence of physical parameters on the TEs bioaccumulation. Results are shown in Fig. 2 and Table 1S. Differences between TEs concentrations were examined taking into consideration the intra-specific variability.

- Influence of the light: During the sample collection carried out in February 2016 (first sampling), three specimens of C. damicornis were collected at the entrance of a cave and two others inside the cave. Considering the intra-species variability, TEs concentrations were similar in the two cave sites. Slight differences were found on the mean $\mathrm{Ni}$ and As concentrations, but not so significant when considering respective RSD. Ni average is $3 \pm 1 \mathrm{mg} \mathrm{kg}^{-1}$ for sponges collected in the cave entrance and $5 \pm 1 \mathrm{mg} \mathrm{kg}^{-1}$ for those collected inside the cave. Unlikely, As was found in higher concentration in samples from the cave entrance: $85 \pm 15$ vs $67 \pm 4 \mathrm{mg} \mathrm{kg}^{-1}$.

- Influence of the depth: During the second sample collection, three samples of $C$. nucula were collected at $5 \mathrm{~m}$ depth and other three specimens at $20 \mathrm{~m}$ depth. TEs concentrations were generally similar for the two sampling depths. Variability in Mo was borderline $\left(2.1 \pm 0.3\right.$ and $1.52 \pm 0.08 \mathrm{mg} \mathrm{kg}^{-1}$, for 5 and $20 \mathrm{~m}$ depth respectively), and $\mathrm{V}$ and Cd concentrations were slightly higher in samples collected at a depth of $20 \mathrm{~m}$ than at $5 \mathrm{~m}$. Slight differences 


\section{${ }^{120}$ First sampling}
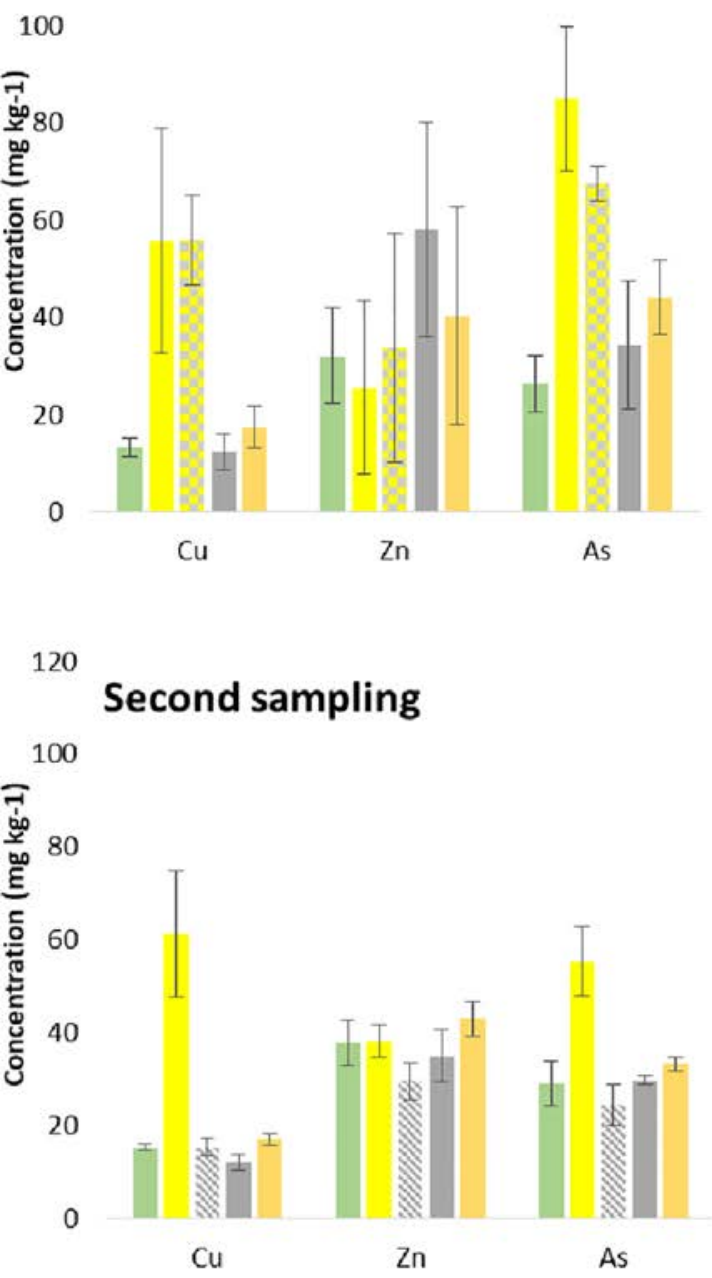

30

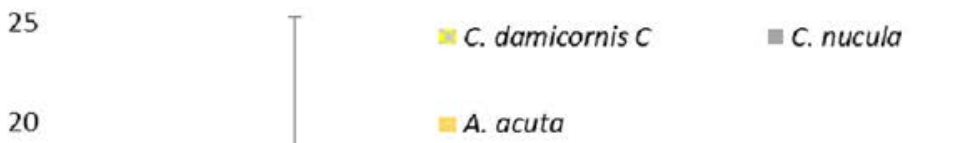

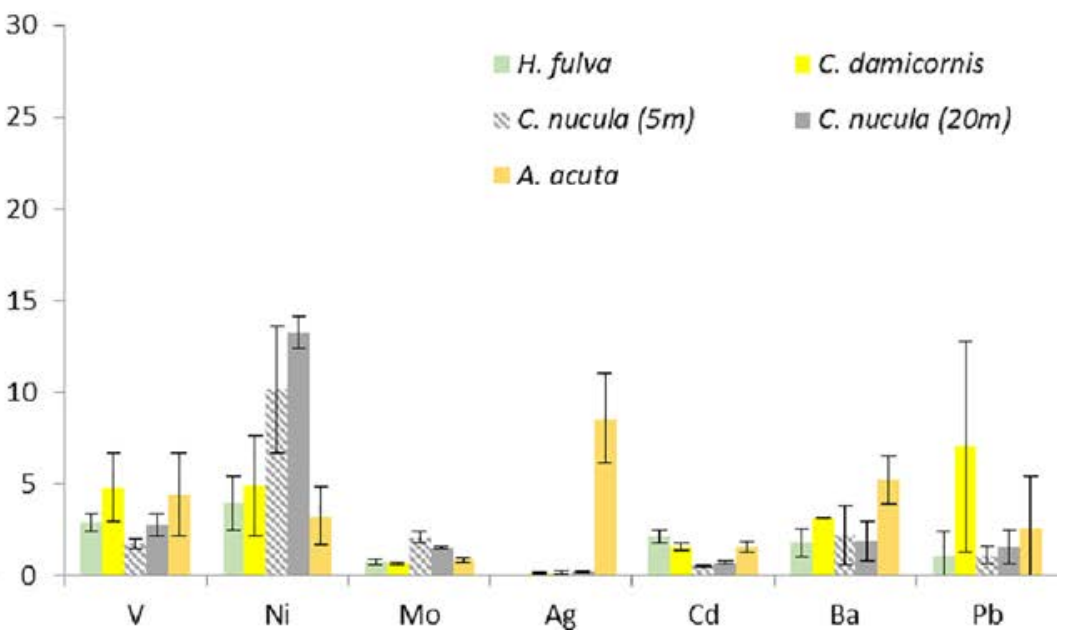

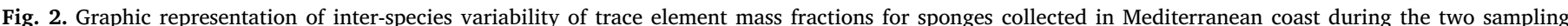

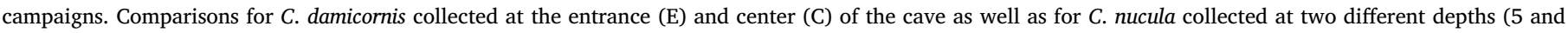
$20 \mathrm{~m}$ ), are also presented. Error bars stand for standard deviations on mean TE values obtained for different specimens of same sponge specie ( $n \geq 3$ ).

occur also on the mean $\mathrm{Cu}$ and As sponge contents, but not significant considering the intra-specific variability.

Overall, small changes in the sampling location and/or depth do not have a significant impact on TEs accumulation in sponges. These organisms can thus be considered representative of a rather spread "zone" of environment, showing consistent and homogeneous TEs distribution within the same sampling period.

- Influence of the sampling season

Mediterranean sponges were collected at the same site during two seasons to estimate the influence of temporal variations in TEs bioaccumulation. The average values obtained for each specie in each season were compared, and differences were evaluated taking into consideration the intra-specific natural variability observed for each pool of specimens. Results are shown in Table 1S.

Considering the intra-specific variability, TEs bioconcentrations were overall similar for the two sampling seasons, especially for $C$. nucula and A. acuta. However, for some of them, concentrations were slightly higher during the first sampling carried out in September 2016 (summer): for As in A. acuta sponges, for $\mathrm{Mo}$ and $\mathrm{Pb}$ in C. nucula sponges, for $\mathrm{Ba}, \mathrm{As}, \mathrm{Mo}$ and $\mathrm{Ag}$ in C. damicornis, and for $\mathrm{V}, \mathrm{Ni}, \mathrm{Ag}, \mathrm{Ba}$ and $\mathrm{Pb}$ in $H$. fulva sponges. Overall, most of TEs presented none or negligible seasonal fluctuations considering RSD values. If a common trend of TEs enrichment in all sponge species were observed for a sampling period, this could signify an external increased input (e.g. from anthropogenic activities). But this behavior was not observed in sediment samples, as presented in one of the following paragraph. These fluctuations are most likely associated with natural processes: e.g. linked to changes in biological activities of associated bacteria, physio-chemical changes in the water column affecting the uptake and elimination of TEs.

\subsubsection{Inter-specific variability}

\section{- Mediterranean sponges}

The differences in TEs contents between different species were first evaluated for Mediterranean sponges. Since four different species were collected for two different sampling campaigns, it was possible to carry out a comparative study on the different accumulation properties of these species (Fig. 2).

The accumulation of TEs within sponges depends on the considered element. For instance, $\mathrm{As}, \mathrm{Cu}$ and $\mathrm{Zn}$ presented the highest contents in all species. Additionally, the accumulation of TEs strongly depends on 


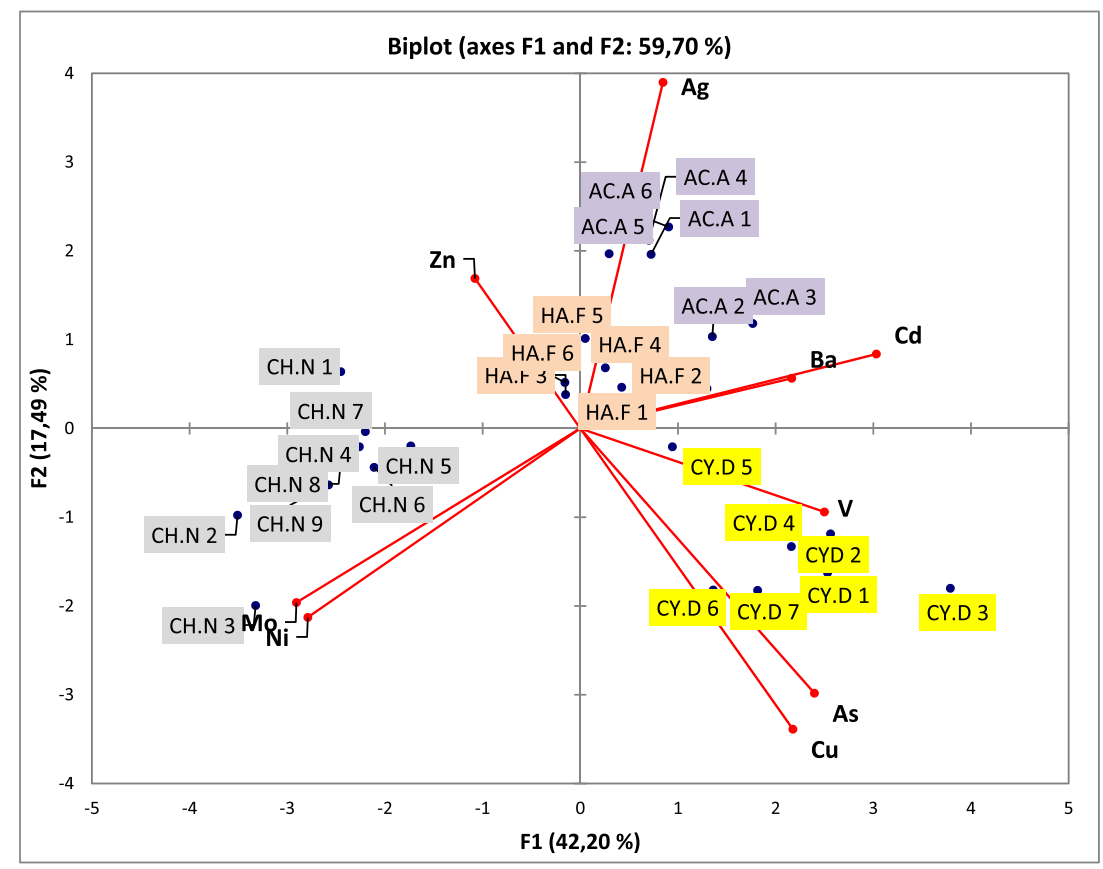

Fig. 3. Biplot representation of PCA performed on all mass fractions found in Mediterranean sponge specimens analyzed in this study.

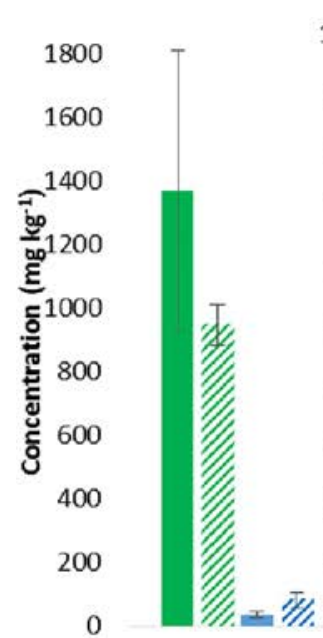

$\mathrm{Zn}$

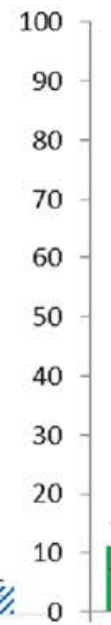

$\checkmark$

$$
\begin{aligned}
& \text { घH. perlevis Kilkieran } \\
& \text { そH. perlevis Belfast }
\end{aligned}
$$

ㅂ. H. panicea Kilkieran

\%.H. panicea Belfast

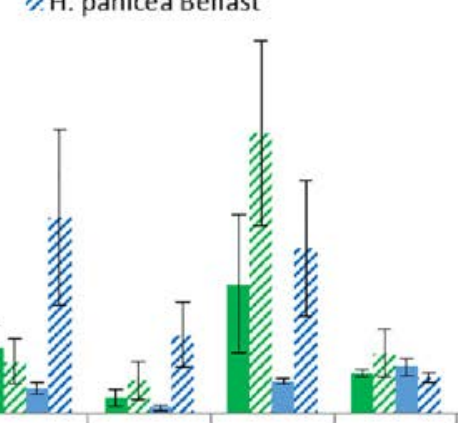

$\mathrm{Ni}$

$\mathrm{Cu}$
As

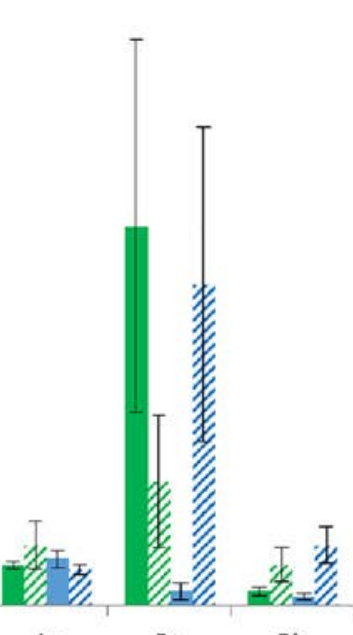

Ba $\quad \mathrm{Pb}$
$\mathrm{Pb}$

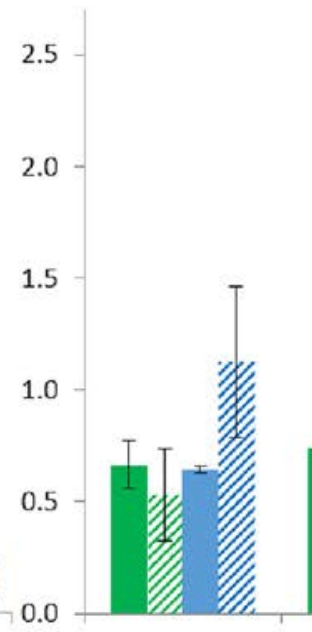

Mo

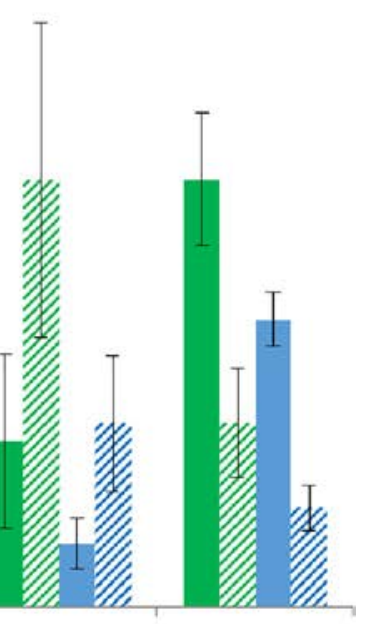

$\mathrm{Ag}$

Cd

Fig. 4. Graphic comparison between TE concentrations on $H$. panicea and $H$. perlevis collected in two sampling locations in Ireland.

the sponge species. C. damicornis showed about two times higher As and $\mathrm{Cu}$ concentrations than other species: between 56 and 61 and $55-85 \mathrm{mg} \mathrm{kg}^{-1}$, respectively. The highest content of $\mathrm{Ni}$ and Mo were found in C. nucula, with values twice (or more) higher than for other species. Zn showed also higher content in C. nucula, but only for the first sampling. The lowest $\mathrm{Cd}$ and $\mathrm{V}$ concentrations were revealed in $C$. nucula sponges. In this study, $\mathrm{Ba}$ and $\mathrm{Pb}$ accumulation in sponges was not shown to be specific to a sponge species. This result can be also due to high intra-species variations and seasonal variations previously described. A peculiar behavior was observed for $\mathrm{Ag}$ in $\mathrm{A}$. acuta, which showed content up to 100 times higher than those found in the other three species. It is worth noticing that $H$. fulva is the only sponge species which did not exhibit a specific affinity for any TE comparing to the other sponge species.

A statistical analysis was performed to better describe the interspecific variations. The biplot obtained by Principal Component Analyses (PCA) is presented in Fig. 3. The first two components (F1 and F2) explained $59.6 \%$ of the total variance. F1 accounted for $42.2 \%$ of total variance and $17.49 \%$ for $\mathrm{F} 2$. High positive loadings of $\mathrm{V}, \mathrm{Cu}$, As, $\mathrm{Cd}$ and $\mathrm{Ba}$ and high negative loadings of $\mathrm{Ni}$ and Mo characterized the F1 axis. The F2 axis was mainly characterized by a Ag positive loading. These observations and the analysis of Fig. 3 led to the conclusions that a positive correlation ( $p<0.05$ ) was found for $\mathrm{V}, \mathrm{Cu} \mathrm{As}, \mathrm{Cd}, \mathrm{Ba}$ and for $\mathrm{Mo}$ and $\mathrm{Ni}$; these two groups of elements being negatively correlated between them. Ag was the only element that did not present any significant correlation with other analytes and thus it is the only one with high positive loadings on F2. The biplot graph shows four distinct groups, each of them including all specimens of the same species. These statistical results confirm the first observations on TEs concentrations and that sponge species can be distinguished based on their TEs bioaccumulation. This biplot highlights: (1) that C. damicornis accumulates preferentially As and $\mathrm{Cu}$; (2) C. nucula Mo and Ni; (3) and an exceptional affinity of A. acuta for Ag; (4) no specificity for $H$. fulva was highlighted. Since Mediterranean sponges were collected in the same site and at the same date, we can assume that they were exposed to the same amount of TEs. The great differences in TEs accumulation in these 


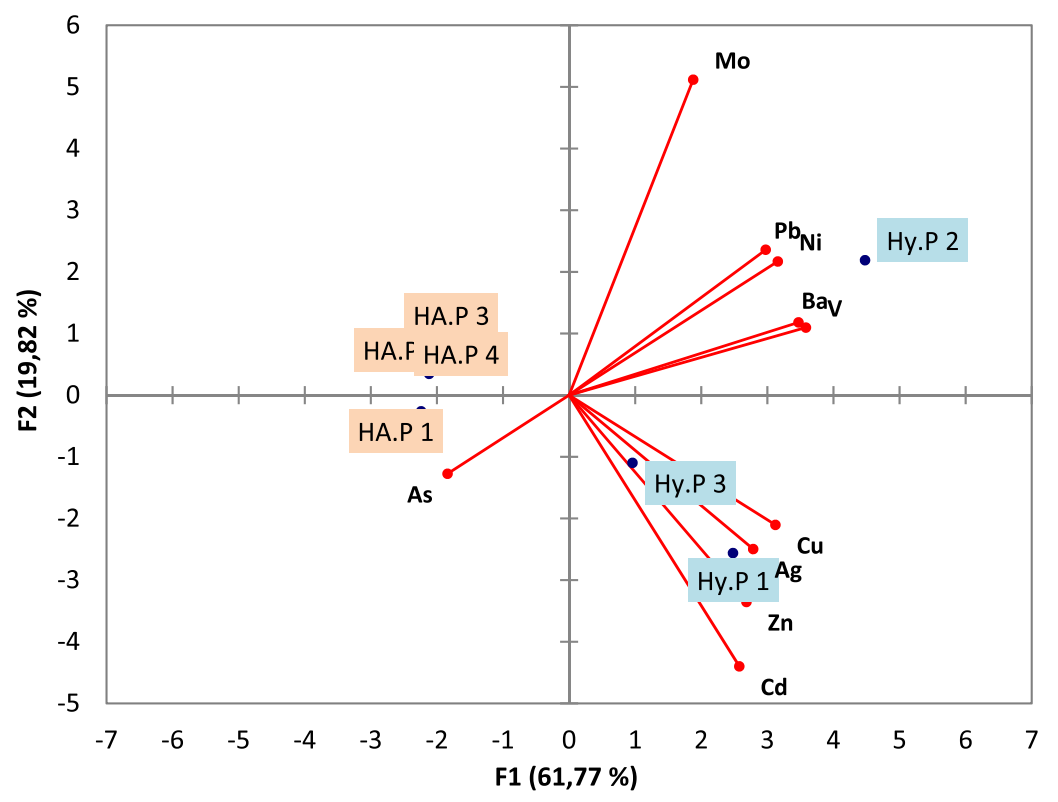

b)

Biplot Belfast samples (axes F1 and F2: 87,1 \%)

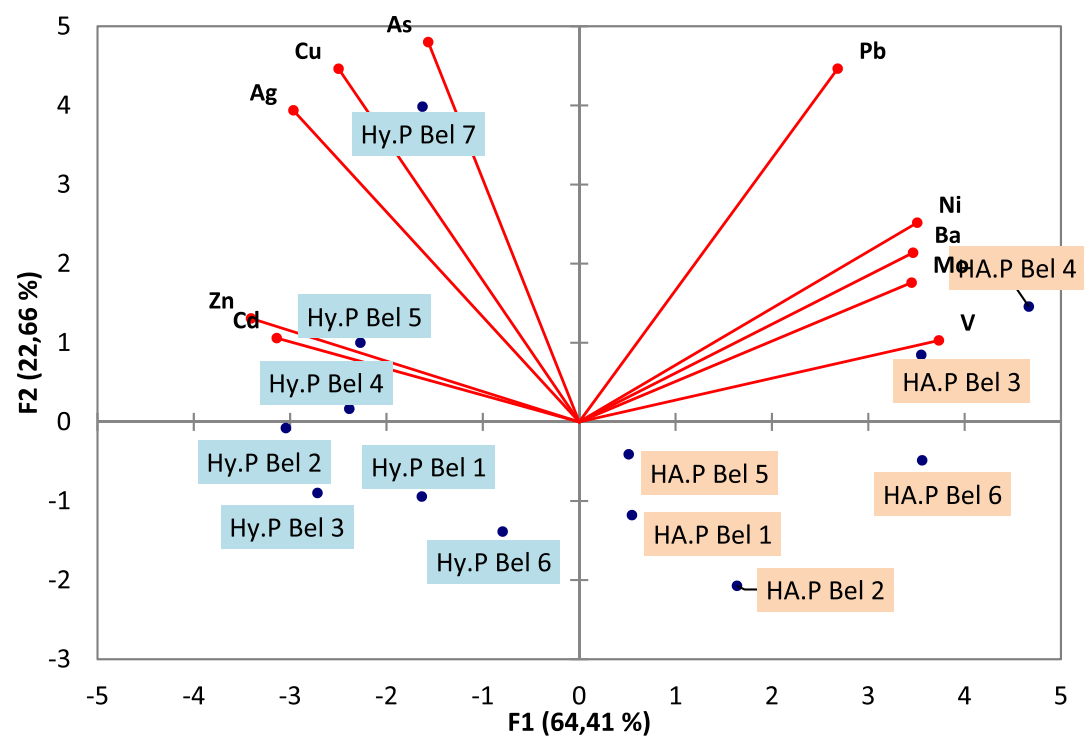

Fig. 5. Biplot representation of PCA performed on mass fractions found in Irish sponges collected in a) Kilkieran bay and b) Belfast lough.

sponges it is thus related to particular characteristics of a sponge specie.

\section{- Irish sponges}

The inter-species variability of TEs concentrations were then evaluated for two sponge species collected in two Irish sampling sites. The results are shown in Fig. 4 and Table 2S. Principal Component Analysis was also performed separately for each sampling site in Ireland to highlight unique properties of each species, not considering differences on element availability in the surrounding seawater. Results are presented in two separated biplots (Fig. 5).

In the quite pristine area of Kilkieran bay, $H$. perlevis sponges revealed higher TEs concentrations than those measured in $H$. panicea, except for As and Mo with similar contents. The PCA results gave two components (F1 and F2) with eigenvalues higher than one, which explained the $81.6 \%$ of variance (Fig. 5 a). F1 was characterized by high positive loadings of all analytes except As, the only element presenting negative contribution to this component. The F2 presented the highest positive loading of Mo and the highest one of $\mathrm{Cd}$, while others TE show low positive or negative contribution. The separation of sponge species in the biplot is evident, as $H$. panicea specimens are grouped in the negative part of F1 while $H$. perlevis are grouped on the opposite side. Even though the As contents in these two species were similar, this metalloid seems to unequivocally distinguish the two sponge species in the PCA. Additionally, it can be noted that $\mathrm{Cu}, \mathrm{Ag}, \mathrm{Zn}$ and $\mathrm{Cd}$ form a first group whereas $\mathrm{Pb}, \mathrm{Ni}$, Ba and $\mathrm{V}$ another one. TEs forming the first group close to the $H$. perlevis samples agrees with the observation of higher $\mathrm{Cu}, \mathrm{Ag}, \mathrm{Zn}$ and $\mathrm{Cd}$ contents in $\mathrm{H}$. perlevis sponges and thus specific affinity for this sponge species.

At the more contaminated site of Belfast Lough, $H$. perlevis sponges 
Table 5

Summary of TE concentrations found in all sediments samples analyzed in this study. Standard deviations were calculated considering different samples collected in the same sampling site. The $\mathrm{n}$ refers to the number of specimens analyzed for each sponge specie.

\begin{tabular}{llll}
\hline Concentrations in & Sampling stations & \\
\hline sediments $\left(\mathrm{mg} \mathrm{kg}^{-1}\right)$ & Villefranche $(n=6)$ & Killkieran $(n=3)$ & Belfast $(n=3)$ \\
$\mathrm{V}$ & $9.5 \pm 0.3$ & $47 \pm 1$ & $59 \pm 9$ \\
$\mathrm{Ni}$ & $4.9 \pm 0.2$ & $10.9 \pm 0.7$ & $22 \pm 3$ \\
$\mathrm{Cu}$ & $3 \pm 0.7$ & $9 \pm 5$ & $7 \pm 1$ \\
$\mathrm{Zn}$ & $21 \pm 2$ & $49 \pm 11$ & $63 \pm 9$ \\
$\mathrm{As}$ & $7 \pm 1$ & $7 \pm 2$ & $2.9 \pm 0.3$ \\
$\mathrm{Mo}$ & $0.3 \pm 0.1$ & $0.35 \pm 0.07$ & $0.12 \pm 0.02$ \\
$\mathrm{Ag}$ & $0.17 \pm 0.01$ & $0.14 \pm 0.08$ & $0.10 \pm 0.06$ \\
$\mathrm{Cd}$ & $0.5 \pm 0.4$ & $0.08 \pm 0.03$ & $0.26 \pm 0.03$ \\
$\mathrm{Ba}$ & $10 \pm 2$ & $151 \pm 24$ & $142 \pm 13$ \\
$\mathrm{~Pb}$ & $13 \pm 4$ & $8.7 \pm 0.7$ & $5.6 \pm 0.3$ \\
\hline
\end{tabular}

revealed also significant higher concentrations for $\mathrm{Cu}, \mathrm{Cd}, \mathrm{Ag}$ and $\mathrm{Zn}$, similar contents of As and Mo and lower concentrations for $\mathrm{V}$, Ni and $\mathrm{Ba}$. The PCA results gave two components (F1 and F2) with eigenvalues higher than one, which accounted for $87.1 \%$ of the total variance. The $\mathrm{F} 1$ was characterized by high positive values of $\mathrm{V}, \mathrm{Ni}, \mathrm{Mo}, \mathrm{Ba}$ and $\mathrm{Pb}$ and by high negative loadings of $\mathrm{Cu}, \mathrm{Zn}, \mathrm{Ag}$ and $\mathrm{Cd}$. The second component $\mathrm{F} 2$ shows high positive contribution from $\mathrm{As}, \mathrm{Pb}, \mathrm{Ag}$ and $\mathrm{Cu}$ and while in this case none of the factors gave negative contribution. The biplot shows again a clear separation between the two species, even if the samples appear to be quite scattered in the graph (Fig. 5b). Specifically, specimens of $\mathrm{H}$. perlevis are grouped in the negative part of $\mathrm{F} 1$, close to $\mathrm{Zn} / \mathrm{Cd}$ or $\mathrm{Cu} / \mathrm{Ag}$ loadings but additionally characterized by negative scores in both F1 and F2. Specimens of $H$. panicea, on the other hand, are distinguishable as they show factors always positive in F1 and almost always negative in F2 (except for specimens HP Bel 3 and 4). While $H$. perlevis is characterized by its $\mathrm{Cd}$ and $\mathrm{Zn}$ accumulation, $H$. panicea separation is most likely related to $\mathrm{Ba}, \mathrm{Mo}, \mathrm{Ni}$ and $\mathrm{V}$.

In conclusion, this survey on two sampling sites demonstrated that: (1) H. perlevis is characterized by higher affinity for $\mathrm{Cu}, \mathrm{Cd}, \mathrm{Ag}$ and $\mathrm{Zn}$ than $H$. panicea sponges; and (2) the remaining TE are not specifically accumulated by one of these two sponge species. The difference on $\mathrm{Zn}$ concentrations between both sponge species is considerable (at least 10 times more). Similarly, to Ag in A. acuta, $H$. pervelis present an outstanding feature to accumulate $\mathrm{Zn}$.

\subsubsection{Inter-site variability}

For Irish sponges, the difference on TE bioaccumulation according to TE availability in the surrounding environment was investigated. Same species of Irish sponges were collected in two different sampling sites: a relatively uncontaminated area (Kilkieran Bay) and in a more contaminated environment (Belfast Lough). Within the intra-specific variability, the comparison of TEs concentrations in sponges highlights significant differences according to the sampling site (Fig. 4).

Except for As and Cd, H. panicea from Belfast showed higher TEs concentrations than those in Kilkieran: 2-3 times higher for Zn, Ag and Mo; 6-10 times higher for $\mathrm{Ni}, \mathrm{Zn}, \mathrm{Cu}$ and $\mathrm{Pb}$; and $>20$ times higher for Ba. On the contrary, As and Cd presented higher concentrations in $H$. panicea from Kilkieran. For $H$. perlevis sponges, $\mathrm{Ni}, \mathrm{Cu}, \mathrm{Pb}$ and $\mathrm{Ag}$ revealed significant higher concentrations in Belfast than those in Kilkieran; whereas Zn, Ba and Cd revealed significant higher concentrations in Kilkieran. Considering the intra-specific variability, these results led to a first conclusion. Belfast is likely to be more contaminated than Kilkieran for $\mathrm{Ni}, \mathrm{Cu}, \mathrm{Pb}$ and $\mathrm{Ag}$, whereas Kilkieran would be more contaminated in $\mathrm{Cd}$. The inter-site variability being opposite or similar within the sponge species for the other TEs (Zn, V, As, Ba, Mo), nothing can be concluded on the other TEs bioavailability in the surrounding environment.

The great differences in TEs accumulation in sponges and other organisms can have different explanations: TE bioavailability and specific chemistry, geochemical influence on the TEs availability in the environment as well species-specific physiological characteristics (Luoma and Rainbow, 2005).

\subsection{TE bioaccumulation in sponges}

A common way to interpret the accumulation of TE in organisms' tissue is the Bio-Concentration Factors (BCF). This parameter has been found useful in the evaluation of the sponge ability to accumulate the analyte with respect to its availability in the environment. According to the definition given by Rand et al. (1995), the bioconcentration is defined as the uptake of a chemical by an organism from the abiotic environment (non-living chemical and physical components of the environment that affect the living organisms, for instance sunlight, soil, water and pollution). Usually BCF for sponges are calculated as the ratio between the chemical concentrations measured in the organism and the one measured in local sediment (Negri et al., 2006; Mayzel et al., 2014; Pan et al., 2011). Value of 1 was set as threshold for all analytes, with results equal or above 1 being considered indicative of bioconcentration. When TE concentration in seawater is included in the study, the BAF are also calculated by dividing the TE sponge's content by the one found in seawater (Padovan et al., 2012; Venkateswara Rao et al., 2009; Batista et al., 2014).

\subsubsection{Bio-concentration factors (BCF)}

TEs concentration found in sediments from the three sampling sites are shown in Table 5. Overall, the values are typical of uncontaminated areas, based on the principal environmental regulations (US EPA, 2006; Split and Delta, 2010). We must emphasize that the grain size distribution appeared to be quite inhomogeneous, and the appearance was typical of sandy samples. These characteristics might explain the relatively low values and the high standard deviation for some elements among replicates collected in the same station (especially for Irish samples). Higher concentrations of $\mathrm{V}, \mathrm{Ni}, \mathrm{Cu}, \mathrm{Zn}$, and Ba were observed for sediments collected at Irish sites than at the French one. Similar Ag contents were measured in sediments regardless of the sampling site. $\mathrm{Cd}$ and $\mathrm{Pb}$ presented higher concentrations in the French site. Finally, the French site and Kilkieran sampling site presented similar Mo and As contents in sediments, higher than those from the Belfast site. Comparing the two Irish sites, sediments revealed similar concentrations for most TE, except Ni, Cd, As and Mo. As and Mo revealed higher concentrations in sediments from Kilkieran, whereas $\mathrm{Ni}$ and $\mathrm{Cd}$ exhibited higher concentrations in Belfast's samples.

In Belfast samples the higher Ni concentration in sediments is in accordance with higher Ni sponge contents. The bioavailability of $\mathrm{Ni}$ is thus suggested to be traced by Ni sponge content. Cd and Mo were found in higher concentration in sponges from Kilkieran and Belfast, respectively; which is the opposite in sediments. For As, even if Irish sediments present significant differences on their concentrations, sponge contents were similar.

The BCF for Mediterranean and Irish sponges are presented in Table 6. BCF obtained for $\mathrm{V}, \mathrm{Pb}, \mathrm{Ba}$ and $\mathrm{Ni}$ were lower than 1 (or close) regardless of the sponge species, leading to the conclusion that these elements are more accumulated in sediments than in sponge' tissue. Ba was demonstrated to be toxic for some sponges (Ostrom and Simpson, 1978; Tompkins-MacDonald et al., 2009), and its BCF were already reported lower than 1 in several sponges species (Mayzel et al., 2014), thus implying its non-essential role in sponges' biological activities. In the same manner, a similar assumption can be made for $\mathrm{V}$, which showed the same behavior in other sponge species, as reported by Mayzel et al. (2014). BCF for Pb were however close or higher than one, only in sponges collected in Belfast. BCF for Ni were found to be higher than one only for H. fulva and C. nucula. This behavior in C. nucula can be explained by a high concentration of dense collagen in this species (Pronzato, 2004). This intertwined network of proteins should have 
Table 6

Average bioconcentration factors calculated for the sponge species analyzed in this study.

\begin{tabular}{|c|c|c|c|c|c|c|c|c|c|c|}
\hline \multirow[t]{2}{*}{ Sponge species (site) } & \multicolumn{10}{|c|}{ Average BCF } \\
\hline & $\mathrm{V}$ & $\mathrm{Ni}$ & $\mathrm{Cu}$ & $\mathrm{Zn}$ & As & Mo & $\mathrm{Ag}$ & $\mathrm{Cd}$ & $\mathrm{Ba}$ & $\mathrm{Pb}$ \\
\hline $\begin{array}{l}\text { H. fulva } \\
\quad \text { (Villefranche) }\end{array}$ & 0.4 & 1.2 & 4.8 & 1.5 & 3.8 & 2.6 & 0.3 & 3.9 & 0.6 & 0.3 \\
\hline $\begin{array}{l}\text { C. damicornis } \\
\text { (Villefranche) }\end{array}$ & 0.6 & 0.9 & 18.1 & 1.6 & 9.0 & 2.4 & 1.0 & 3.9 & 0.6 & 0.4 \\
\hline $\begin{array}{l}\text { A. acuta } \\
\quad \text { (Villefranche) }\end{array}$ & 0.5 & 0.6 & 5.7 & 2.0 & 5.4 & 2.3 & 41.1 & 3.7 & 0.6 & 0.3 \\
\hline $\begin{array}{l}\text { C. nucula } \\
\qquad \text { (Villefranche) }\end{array}$ & 0.3 & 2.8 & 4.4 & 1.8 & 4.1 & 6.3 & 1.3 & 1.3 & 0.2 & 0.2 \\
\hline $\begin{array}{l}\text { H. panicea } \\
\quad \text { (Kilkieran) }\end{array}$ & 0.1 & 0.1 & 0.6 & 0.8 & 1.2 & 1.8 & 2.1 & 21.2 & 0.02 & 0.2 \\
\hline H. panicea (Belfast) & 0.6 & 0.6 & 4.3 & 1.3 & 2.1 & 9.3 & 8.4 & 1.7 & 0.4 & 1.8 \\
\hline H. perlevis (Kilkieran) & 0.2 & 0.2 & 2.5 & 27.8 & 1.0 & 1.9 & 5.4 & 31.5 & 0.4 & 0.3 \\
\hline H. perlevis (Belfast) & 0.2 & 0.3 & 7.2 & 15.1 & 3.5 & 4.4 & 19.7 & 3.2 & 0.1 & 1.2 \\
\hline
\end{tabular}

strong affinity with these pure transition metals, maybe due to the presence of basic amino acids acting as ligands for these transition metals. C. nucula is also a HMA (high microbial abundance, Vacelet and Donadey, 1977) and the associated cyanobacteria can be responsible for the observed behavior.

For all the other TEs (Cu, Zn, As, Mo, Ag, Cd), BCF were consistently higher than one. $\mathrm{Cd}$ and $\mathrm{Cu}$ were found to be accumulated by several sponges species collected in the Red and Mediterranean seas (Pan et al., 2011; Mayzel et al., 2014; Cebrian et al., 2007), highlighting their essential role in sponges' metabolism. The high $\mathrm{Zn}$ bioaccumulation is likely to be associated not only to its geochemical availability, but also to its crucial role in multiple biological processes as well as to its higher uptake rate for species of this family (Rainbow, 2002). This element is also present in all six classes of enzymes (Broadley et al., 2007), it is thus not surprising that $\mathrm{Zn}$ is actively accumulated by sponges. The specific bioconcentration of these TEs could also be associated to some adsorption phenomena related to particular biomolecules such as collagen, as already proposed for $C$. nucula.

The inter-site and inter-species variations of BCF are shown in Fig. 6. Except for Cd and Zn, all the BCFs calculated for Belfast samples were higher than those determined in Kilkieran sponges, despite the similar (V, Cu, Ag, Ba) or lower (As, Mo, Pb) content in sediments. This is particularly evident for $\mathrm{Cu}, \mathrm{As}, \mathrm{Mo}, \mathrm{Ag}$ and $\mathrm{Pb}$. Additionally the $\mathrm{BCF}$ found for $H$. perlevis were generally higher than those calculated for $H$. panicea, sampling site being equal. Even if the massive shape of $H$. panicea should yield to higher water pumping rate, the bioaccumulation is higher for $H$. perlevis, thus other factors must be involved in the bioaccumulation processes. $H$. perlevis is a HMA sponge with several associated cyanobacteria described in this species (Alex et al., 2012) which can influence the bioaccumulation. Additionally, a tyrosine derivative has recently been found in this species, which can have a role in the TEs complexing (Mahajan et al., 2017). C. damicornis showed the highest $\mathrm{BCF}$ for $\mathrm{Cu}$ and As compared to other species (BCF $=18$ and 9, respectively). Like $H$. fulva and $A$. acuta, this species is characterized by a low microbial abundance (LMA) (Vacelet and Donadey, 1977) with original bacterial community. The branch erected shape and in general the specie's shape cannot be responsible for a higher TEs accumulation as no correlation was found between the accumulation and the morphology. Instead, two reasons can explain the high concentration of As and $\mathrm{Cu}$ in C. damicornis: first a unique associated microbiota can be selective of these two TEs and the second option would be that high concentrations of secondary metabolites can complex these TEs. It is indeed know that pyrrole aminoimidazole metabolites are highly present in this species (Aiello et al., 2005). They can complex specifically $\mathrm{Cu}$ due to the presence of basic nitrogens, however for As associated bacteria may be a better explanation. Arsenic was previously shown to be highly accumulated by sponges, reaching concentration values above $100 \mathrm{mg} \mathrm{kg}^{-1}$ (Pan et al., 2011; Yamaoka et al., 2006; Araújo et al., 2003). Arsenic accumulation was also demonstrated to be higher in demosponges than calcareous sponges (Yamaoka et al., 2001), and additionally quite variable among demosponges as demonstrated in the present study with a particular affinity for C. damicornis. Arsenic bioaccumulation and speciation were recently discussed in a published paper and the study underlines the potential role of this metalloid (and more specifically of arsenobetaine) in the protection of sponges against osmolytic stress (Orani et al., 2018). A new polyarsenic compound was also found in a sponge specie from New Caledonia (Mancini et al., 2006), opening the debate on a clear role of this element in sponges' metabolism.

As already observed in $\mathrm{Zn}$ concentrations results, $\mathrm{Zn} \mathrm{BCF}$ were the highest in $H$. perlevis sponges ( $\mathrm{BCF}=15-28$ ) regardless of the sampling site, showing a clear affinity of the species for this element. The highest $\mathrm{BCF}$ was found in $A$. acuta sponges for $\mathrm{Ag}(\mathrm{BCF}=41.1)$, as expected from the higher concentrations measured in this sponge specie. Similarly to results found in this study, the propensity for Ag accumulation in A. acuta sponges was already observed, also revealing a much reduced Ag decontamination process, compared to other species

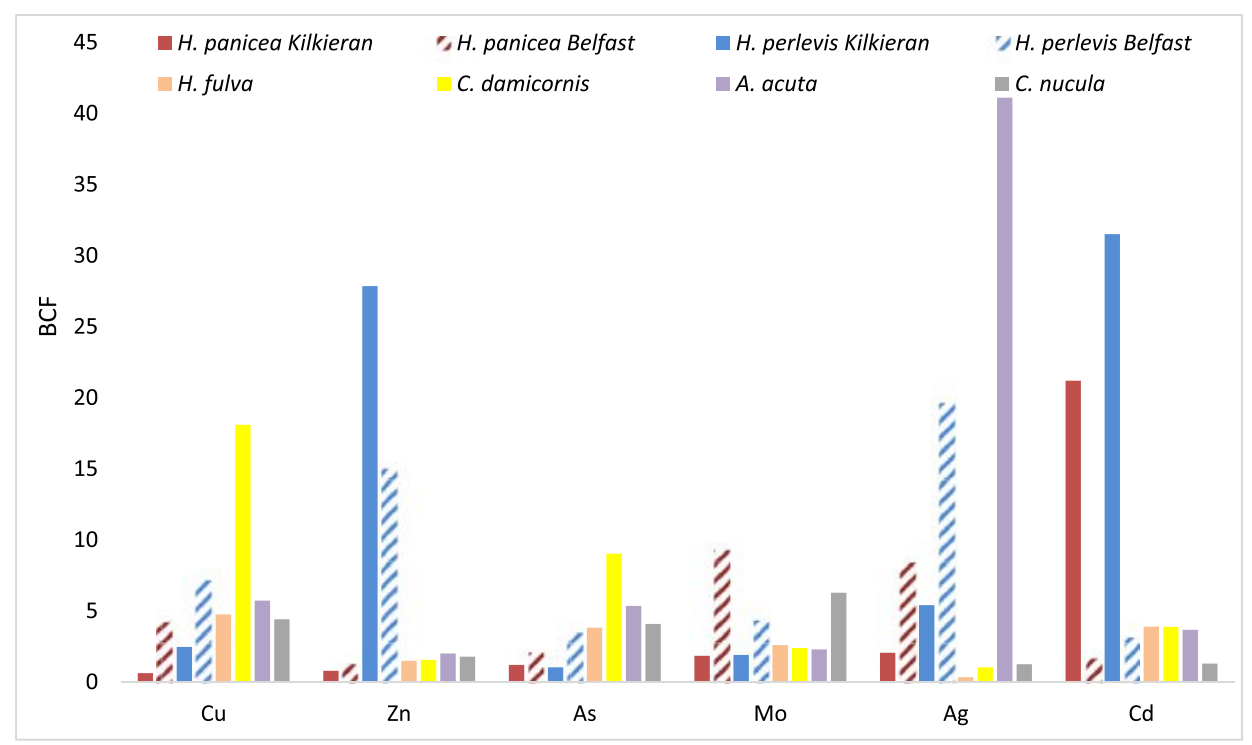

Fig. 6. Graphical representation of some of the Bio-concentration factors calculated for all sponge species. 
(Genta-Jouve et al., 2012). The reason for this particular behavior resides in the role of $\mathrm{Ag}$ in the secondary metabolism of this sponge specie as the sponge is known for containing high concentration of nitrile and isonitrile secondary metabolites which have strong affinity for silver ions. High Ag BCF values were also observed for Irish sponges, reaching 19.7 for $H$. perlevis in Belfast. Concerning Mo, its BCF is significantly higher for $C$. nucula among the in Mediterranean sponges $(\mathrm{BCF}=6.3$ ), and in $H$. panicea and $H$. perlevis in Belfast $(\mathrm{BCF}=9.3$ and 4.4, respectively). It is worth noticing that Mo bioaccumulation is higher in sponges from Belfast $(\mathrm{BCF}=21.2-31.5)$ whereas Mo sediment content was significantly lower in Belfast than in Kilkieran. Mo was seldom included in TEs accumulation studies performed on sponges. Gentric et al. (2016) reported Mo sponge concentrations between 0.2 and $1.2 \mathrm{mg} \mathrm{kg}^{-1}$ (similar to those measured in this study), showing a special affinity of this element for the specie $H$. perlevis comparing to the Raspailia ramosa species. Cd presented the same opposite behavior between sponge and sediment results. Cd BCF in both Irish sponge species were surprisingly high in Kilkieran Bay $(21-31)$ whereas the Cd content in sediments was significantly lower in this sampling site comparing to Belfast. The discrepancy between Cd contamination profiles and accumulation in organisms was already observed in barnacles and mussels (Phillips and Rainbow, 1988) indicating the existence of subtle differences in bioavailability of this element. In other words, Cd bioavailability and thus its uptake is not necessarily proportional to its concentration in sediments or generally in the surrounding environment.

Padovan et al. (2012) reported BCF for the sponge Spheciospongia vagabunda up to 375, 48 and 1850 for $\mathrm{Ni}, \mathrm{Zn}$ and Cd respectively, which is higher than BCF calculated in our study. However, sponges and sediments from this previous study were sampled close to a sewage outfall proving thus large anthropogenic TEs inputs. Similar BCF values were reported by Cebrian et al. (2007) in Northwestern Mediterranean sponges for $\mathrm{Cu}$ and $\mathrm{Pb}$ : i.e. up to 17.5 and up to 0.23 , respectively for Dysidea avara and Chondrosia reniformis, values comparable with maximum BCF for $\mathrm{Cu}$ of 18 in C. damicornis, and similar than usual BCF for $\mathrm{Pb}$ (except in Belfast). Pan et al. (2011) measured TE in different sponges and sediments from Red Sea, showing maximum BCF of 74, 22, 3, 56 and 5 for $\mathrm{Cd}, \mathrm{Zn}, \mathrm{Ag}, \mathrm{Cu}$ and As respectively. These results were higher than those reported in the present study for $\mathrm{Cd}$ and $\mathrm{Cu}$, lower for $\mathrm{Ag}$ and overall comparable for $\mathrm{Zn}$ and As. Mayzel et al. (2014) analyzed 16 sponge species and reported BCF consistently lower than 1 for $\mathrm{Ba}$ (except for one specie) and V; additionally, the study shows BCF $>1$ for As, Cd and Zn. A significant As BCF of 477 was previously measured in only one sponge specie, Theonella swinhoei, which was explained by the presence of a particular bacterium (Mayzel et al., 2014). It is worth noticing that T. swinhoei is a slow growing and long-lived specie. So As concentration could be linked to the age of the sponge and thus responsible for the elevated BCF. Negri et al. (2006) reported also BCF comparable with the present study for $\mathrm{Cu}, \mathrm{Pb}$ and $\mathrm{Zn}$ (not considering H. perlevis), but much higher BCF were reported for As (up to 19) and Cd (up to 690). Results from our study as well as literature data thus support the evidence that the variability in TEs accumulation (and bioconcentration) in sponges occurs at many scales including within and between species, within and between locations, and related to the targeted TE.

\subsubsection{Sponges: a powerful tool for biomonitoring studies}

To better appreciate the extent of TEs bio-concentration in sponges, the results can be compared with values determined in other organisms, potentially used as monitors of TEs in coastal/marine environment. The great advantages of sponges comparing to other "common" biomonitors like bivalves is that they are simple organisms without complex organs and tissues. It is thus reasonable to think that sponge tissues show low intra-individual variation in TE concentrations (de Mestre et al., 2012).

In a baseline study conducted in Guam harbors the Indo-Pacific Ocean, sponges were shown to accumulate consistently higher amounts of $\mathrm{Ag}$, As, $\mathrm{Cd}, \mathrm{Cu}, \mathrm{Ni}, \mathrm{Pb}$ and $\mathrm{Zn}$ in comparison to seaweeds, but not in comparison to oysters or other bivalves (Denton et al., 2006). Aly et al. (2013) found that most of TEs in sponge specimens of $H$. oculata from Poole Harbour (UK) were accumulated much more efficiently than in species of bivalve Cerastoderma edule, a common cockle. The latter showed TEs concentrations lower than sediment for almost all analytes while the sponge exhibited very high BCF. A study published by Perez et al. (2004) also showed that sponges from Mediterranean coasts concentrate more TEs than mussels (Mytilus galloprovialis), exception made for Zn. Depending on the targeted TE, concentrations measured in sponges were from 6 to 145 times higher than those measured in mussels. Gentric et al. (2016) reported also higher concentration values of $\mathrm{Mo}, \mathrm{Ni}$, and $\mathrm{Pb}$ in $H$. perlevis and $R$. ramosa collected in Northern France, in comparison with Crassostrea gigas (oyster). On the other hand, this oyster specie showed much higher content of $\mathrm{Cu}$ and $\mathrm{Zn}$ in comparison with all the sponges species analyzed in the mentioned study. $\mathrm{Cu}$ and $\mathrm{Zn}$ concentrations in oysters were shown to reach $>$ $10,000 \mathrm{mg} \mathrm{kg}^{-1}$ (Weng and Wang, 2014; Birch et al., 2014). Other benthic organisms such as macroalgae, gastropods and nemertean were shown to accumulate TEs in extent more or less comparable to sponges. Majer et al. (2014) reported BCF values up to 2, 8, 2, 0.4, 1.6 and 5.6 for $\mathrm{As}, \mathrm{Cd}, \mathrm{Cu}, \mathrm{Ni}, \mathrm{Pb}$ and $\mathrm{Zn}$ respectively, for different benthic organisms collected in Antarctica. Corals also shown interesting TEs accumulation properties, with $\mathrm{BCF}$ reaching 22 for $\mathrm{Cd}, 7$ for $\mathrm{Pb}, 24$ for $\mathrm{Cu}$ and 66 for Zn (Esslemont, 2000).

In conclusion, elements such as $\mathrm{Ag}$, As, Mo and $\mathrm{Cd}$ seem to have more affinity for sponges in comparison to other organisms. Even if $\mathrm{Cu}$ and $\mathrm{Zn}$ are often better accumulated by other organisms in comparison to sponges, these TEs are also significantly bioconcentrated in sponges. This and previous studies demonstrate that sponges are a good tool for TEs monitoring studies, especially since they are widespread in coastal ecosystems.

\subsection{Source of lead}

In the Mediterranean site, as already mentioned, $\mathrm{Pb}$ showed an unusual high variability within the species. The initial hypothesis was that the sponge samples were exposed to different $\mathrm{Pb}$ sources in different extent, thus leading to very high differences even among specimens of the same species. To assess this hypothesis, the analysis of $\mathrm{Pb}$ isotope ratios was performed in sponge and sediment samples. Results are presented in Fig. 7 and clearly show that all samples have been exposed to the same $\mathrm{Pb}$ source, as the isotopic compositions are practically identical. $\mathrm{Pb}$ isotope ratios were found to be more radiogenic than those reported for gasoline in France (Monna et al., 1995) or average French industrial $\mathrm{Pb}$ (Véron et al., 1999) but closer to values reported for natural $\mathrm{Pb}$ sources i.e. pre-industrial sediments discharged by the major French rivers $\left({ }^{206} \mathrm{~Pb} /{ }^{207} \mathrm{~Pb}=1.197-1.206\right.$, ElbazPoulichet et al., 1986) and Miocene siltstone and Jurassic limestone analyzed by Monna et al. (1995). (See Fig. 8.)

Regarding Irish samples, the $\mathrm{Pb}$ concentrations found in sediments were higher in Kilkieran than in Belfast ( 8.7 vs $5.6 \mathrm{mg} \mathrm{kg}^{-1}$ ) whereas it was the opposite in sponges with higher $\mathrm{Pb}$ contents in Belfast. Threeisotope graphs showed a clear linear trend for Irish samples $\left(\mathrm{r}^{2}=0.9595\right.$, Fig. 7) suggesting that at least two different $\mathrm{Pb}$ sources influenced these samples' isotopic composition. Samples collected in Belfast show lower ${ }^{206} \mathrm{~Pb} /{ }^{207} \mathrm{~Pb}$ as well as lower ${ }^{206} \mathrm{~Pb} /{ }^{204} \mathrm{~Pb}$ values, close to ${ }^{206} \mathrm{~Pb} /{ }^{207} \mathrm{~Pb}$ values reported by Fletcher et al. (1993) for Welsh ore and by Charlesworth et al. (2006) for Dublin surface sediments, influenced by the industrial activities of the area. Charlesworth et al. (2006) also reported ${ }^{206} \mathrm{~Pb} /{ }^{207} \mathrm{~Pb}$ equal to 1.191 for bottom sediment cores collected in the Irish Sea (between Dublin and Belfast). This value is close to our results on sponges and sediment collected in Kilkieran Bay, confirming that the $\mathrm{Pb}$ found in both, sponges and sediment from Killkieran, is most likely associated to a natural source. These results thus show how the mere determination of $\mathrm{Pb}$ concentration is often not 


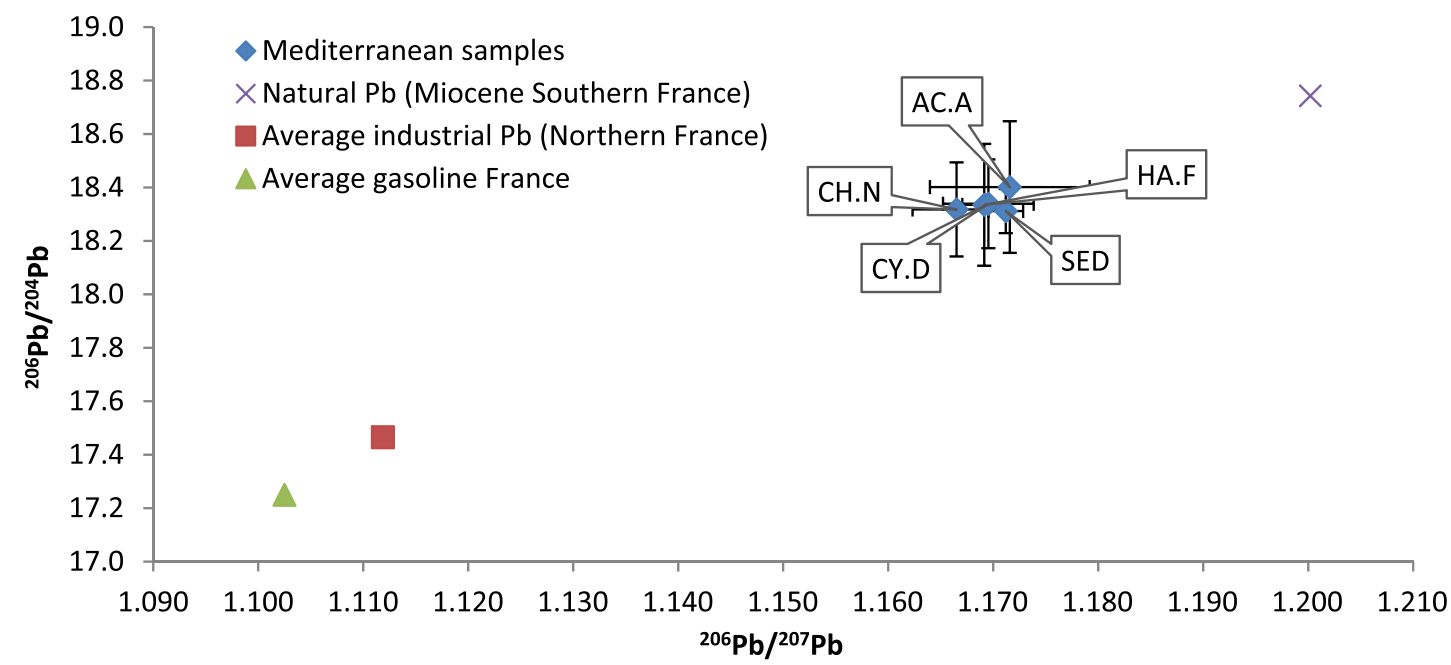

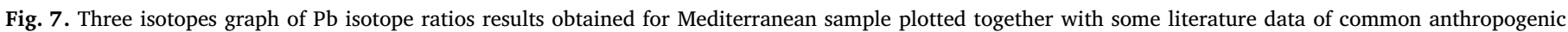
sources and typical natural composition of the area. Data from Elbaz-Poulichet et al. (1986), Monna et al. (1995), Véron et al. (1999).

sufficient for the assessment of contamination of a given place, especially when sediments of proper grain size are not available. The $\mathrm{Pb}$ isotopic composition can give relevant additional information and the ultimate confirmation of the presence of $\mathrm{Pb}$ from anthropogenic source.

\section{Conclusion}

In conclusion, the present work shows the great capabilities of sponges as TEs bioaccumulators and their suitability as environmental biomonitors. The six analyzed species show generally different accumulation properties depending on the considered element, sampling station and sponge species. Some elements such as $\mathrm{Ba}, \mathrm{V}$ and in some cases $\mathrm{Ni}$, were poorly accumulated by sponges, meaning that these elements are not involved in biological processes. Statistical data treatment by PCA and BCF calculations shows how it is possible to distinguish different species based on their bioaccumulation properties. Specifically, $\mathrm{Cu}$ and As are demonstrated to be highly accumulated in C. damicornis, $\mathrm{Zn}$ in $H$. perlevis and, as already shown in previous studies, $\mathrm{Ag}$, Mo and $\mathrm{Ni}$ in A. acuta. Except for $\mathrm{Ba}, \mathrm{V}$ and $\mathrm{Pb}, \mathrm{BCF}$ were higher than one, highlighting the bioaccumulation properties of sponges. Our results show that the bioaccumulation of TEs is most likely associated to specific morphological features and/or to the specific bacterial community associated to different species rather than different pumping rate. This study confirms that sponges are efficient bioindicators of TEs pollution state of coastal environments. Finally, the determination of $\mathrm{Pb}$ isotope ratios, offered the opportunity to evaluate the source of $\mathrm{Pb}$ in the studied area, revealing mostly a natural origin for samples collected in the Mediterranean area (even though the $\mathrm{Pb}$ concentrations were higher than both Irish sites) and Kilkieran bay, while an anthropogenic signature was mainly found in samples collected from Belfast Lough.

\section{Acknowledgment}

The authors would like to express their deep gratitude to J.P. Goudour for his technical assistance in our daily laboratory work, to D. Rodrigues and M. Nicolas for sponge sampling in France and to C. Morrow for sponge sampling in Belfast. A. M. Orani has benefited from a financial support from the University of Nice-Sophia Antipolis and NUI Galway. The IAEA is grateful for the support provided by the Government of the Principality of Monaco to its Environment Laboratories.

\section{Appendix A. Supplementary data}

Supplementary data to this article can be found online at https:// doi.org/10.1016/j.marpolbul.2018.04.073.

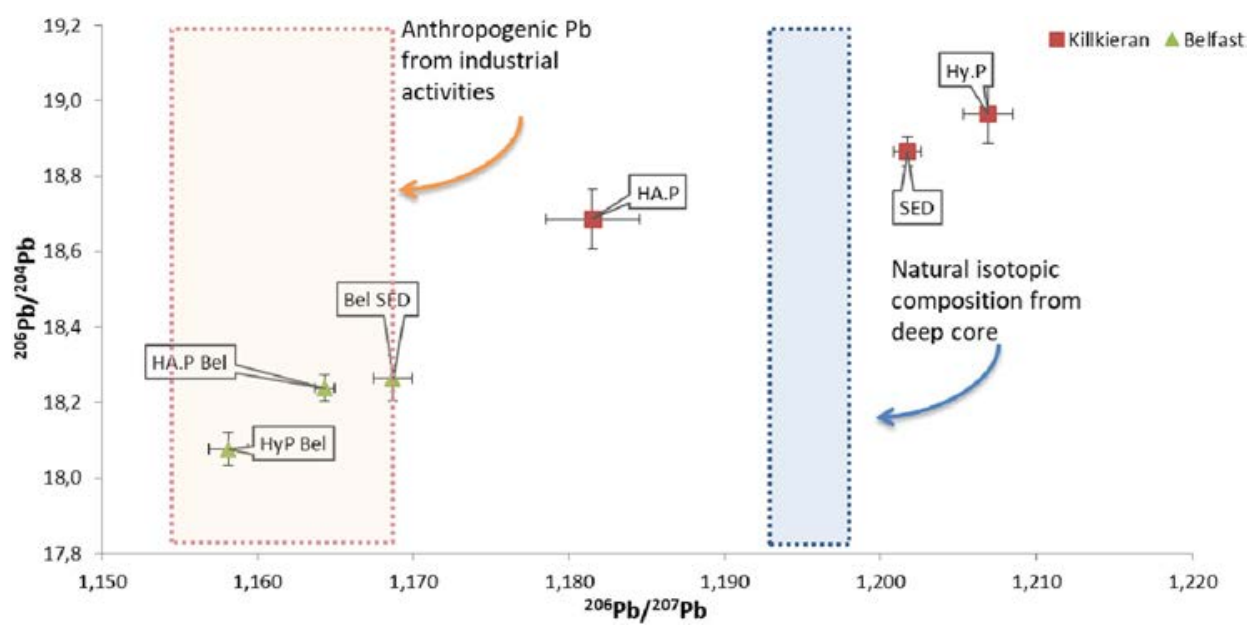

Fig. 8. Three isotopes graphs showing Pb isotope ratios results for sponges and sediments collected in Ireland. Data from Fletcher et al. (1993) and Charlesworth et al. (2006). 


\section{References}

Aiello, A., D'Esposito, M., Fattorusso, E., Menna, M., Müller, W.E.G., Perović-Ottstadt, S., Tsuruta, H., Gulder, T.A.M., Bringmann, G., 2005. Daminin, a bioactive pyrrole alkaloid from the Mediterranean sponge Axinella damicornis. Tetrahedron 61, 7266-7270. http://dx.doi.org/10.1016/J.TET.2005.05.025.

Alex, A., Vasconcelos, V., Tamagnini, P., Santos, A., Antunes, A., 2012. Unusual symbiotic cyanobacteria association in the genetically diverse intertidal marine sponge Hymeniacidon perlevis (Demospongiae, Halichondrida). PLoS One 7, 1-12. http://dx. doi.org/10.1371/journal.pone.0051834.

Aly, W., Williams, I.D., Hudson, M.D., 2013. Metal contamination in water, sediment and biota from a semi-enclosed coastal area. Environ. Monit. Assess. 185, 3879-3895. http://dx.doi.org/10.1007/s10661-012-2837-0.

Anjum, K., Abbas, S.Q., Shah, S.A., Akhter, N., Batool, S., Hassan, S.S., 2016. Marine sponges as a drug treasure. Biomol. Ther. 24, 347-362.

Araújo, M.F., Conceição, A., Barbosa, T., Lopes, M.T., Humanes, M., 2003. Elemental composition of marine sponges from the Berlengas Natural Park, western Portuguese coast. X-Ray Spectrom. 32, 428-433. http://dx.doi.org/10.1002/xrs.660.

Aresta, A., Marzano, C.N., Lopane, C., Corriero, G., Longo, C., Zambonin, C., Stabili, L., 2015. Analytical investigations on the lindane bioremediation capability of the demosponge Hymeniacidon perlevis. Mar. Pollut. Bull. 90, 143-149. http://dx.doi.org/ 10.1016/j.marpolbul.2014.11.003.

Ashraf, A., Saion, E., Gharibshahi, E., Kamari, H.M., Yap, C.K., Hamzah, M.S., Elias, M.S., 2017. Distribution of trace elements in Core marine sediments of coastal East Malaysia by instrumental neutron activation analysis. Appl. Radiat. Isot. 122, 96-105. http://dx.doi.org/10.1016/j.apradiso.2017.01.006.

Barats, A., Féraud, G., Potot, C., Philippinini, V., Travi, Y., Durrieu, G., Dubar, M., Simler, R., 2014. Naturally dissolved arsenic concentrations in the Alpine/Mediterranean Var River watershed (France). Sci. Total Environ. 473-474, 422-436. http://dx.doi.org/ 10.1016/J.SCITOTENV.2013.12.007.

Batista, D., Muricy, G., Rocha, R.C., Miekeley, N.F., 2014. Marine sponges with contrasting life histories can be complementary biomonitors of heavy metal pollution in coastal ecosystems. Environ. Sci. Pollut. Res. 21, 5785-5794. http://dx.doi.org/10. 1007/s11356-014-2530-7.

Birch, G.F., Melwani, A., Lee, J.H., Apostolatos, C., 2014. The discrepancy in concentration of metals $(\mathrm{Cu}, \mathrm{Pb}$ and $\mathrm{Zn}$ ) in oyster tissue (Saccostrea glomerata) and ambient bottom sediment (Sydney estuary, Australia). Mar. Pollut. Bull. 80, 263-274. http://dx.doi.org/10.1016/j.marpolbul.2013.12.005.

Broadley, M.R., White, P.J., Hammond, J.P., Zelko, I., Lux, A., 2007. Zinc in plants. New Phytol. 173, 677-702. http://dx.doi.org/10.1111/j.1469-8137.2007.01996.x.

Cabrita, M.T., Padeiro, A., Amaro, E., dos Santos, M.C., Leppe, M., Verkulich, S., Hughes, K.A., Peter, H.-U., Canário, J., 2017. Evaluating trace element bioavailability and potential transfer into marine food chains using immobilised diatom model species Phaeodactylum tricornutum, on King George Island, Antarctica. Mar. Pollut. Bull. 121, 192-200. http://dx.doi.org/10.1016/j.marpolbul.2017.05.059.

Caccia, V.G., Millero, F.J., Palanques, A., 2003. The distribution of trace metals in Florida Bay sediments. Mar. Pollut. Bull. 46, 1420-1433. http://dx.doi.org/10.1016/S0025326X(03)00288-1.

Cantillo, A.Y., 1998. Comparison of results of mussel watch programs of the United States and France with worldwide mussel watch studies. Mar. Pollut. Bull. 36, 712-717. http://dx.doi.org/10.1016/S0025-326X(98)00049-6.

Cebrian, E., Martí, R., Uriz, J.M., Turon, X., 2003. Sublethal effects of contamination on the Mediterranean sponge Crambe crambe: metal accumulation and biological responses. Mar. Pollut. Bull. 46, 1273-1284. http://dx.doi.org/10.1016/S0025-326X (03)00190-5.

Cebrian, E., Uriz, M.-J., Turon, X., 2007. Sponges as biomonitors of heavy metals in spatial and temporal surveys in northwestern Mediterranean: multispecies comparison. Environ. Toxicol. Chem. 26, 2430-2439. http://dx.doi.org/10.1897/07-292.1.

Charlesworth, M.E., Chenery, S., Mellor, A., Service, M., 2006. Isotopic composition and concentration of $\mathrm{Pb}$ in suspended particulate matter of the Irish Sea reveals distribution and sources. Mar. Pollut. Bull. 52, 81-88. http://dx.doi.org/10.1016/j marpolbul.2005.08.009.

Dahms, S., van der Bank, F.H., Greenfield, R., 2014. A baseline study of metal contamination along the Namibian coastline for Perna perna and Choromytilus meridionalis. Mar. Pollut. Bull. 85, 297-305. http://dx.doi.org/10.1016/j.marpolbul. 2014.05.037.

Denton, G.R.W., Concepcion, L.P., Wood, H.R., Morrison, R.J., 2006. Trace metals in marine organisms from four harbours in Guam. Mar. Pollut. Bull. 52, 1784-1804. http://dx.doi.org/10.1016/j.marpolbul.2006.09.010.

Drivelos, S.A., Georgiou, C.A., 2012. Multi-element and multi-isotope-ratio analysis to determine the geographical origin of foods in the European Union. TrAC Trends Anal. Chem. 40, 38-51. http://dx.doi.org/10.1016/j.trac.2012.08.003.

Elbaz-Poulichet, F., Holliger, P., Martin, J.M., Petit, D., 1986. Stable lead isotopes ratios in major French rivers and estuaries. Sci. Total Environ. 54, 61-76. http://dx.doi.org/ 10.1016/0048-9697(86)90256-1.

Esslemont, G., 2000. Heavy metals in seawater, marine sediments and corals from the Townsville section, Great Barrier Reef Marine Park, Queensland. Mar. Chem. 71, 215-231. http://dx.doi.org/10.1016/S0304-4203(00)00050-5.

Fang, T.-H., Hsiao, S.-H., Nan, F.-H., 2014. Nineteen trace elements in marine copepods collected from the coastal waters off northeastern Taiwan. Cont. Shelf Res. 91, 70-81. http://dx.doi.org/10.1016/j.csr.2014.09.003.

Fletcher, C.J.N., Swainbank, I.G., Colman, T.B., 1993. Metallogenic evolution in Wales: constraints from lead isotope modelling. J. Geol. Soc. Lond. 150, 77-82. http://dx doi.org/10.1144/gsigs.150.1.0076.

Genta-Jouve, G., Cachet, N., Oberhänsli, F., Noyer, C., Teyssié, J.L., Thomas, O.P.,
Lacoue-Labarthe, T., 2012. Comparative bioaccumulation kinetics of trace elements in Mediterranean marine sponges. Chemosphere 89, 340-349. http://dx.doi.org/10 1016/j.chemosphere.2012.04.052.

Gentric, C., Rehel, K., Dufour, A., Sauleau, P., 2016. Bioaccumulation of metallic trace elements and organic pollutants in marine sponges from the South Brittany Coast, France. J. Environ. Sci. Health A 51, 213-219. http://dx.doi.org/10.1080/10934529. 2015.1094327.

Gifford, S., Dunstan, R.H., O'Connor, W., Koller, C.E., MacFarlane, G.R., 2007. Aquatic zooremediation: deploying animals to remediate contaminated aquatic environments. Trends Biotechnol. 25, 60-65. http://dx.doi.org/10.1016/j.tibtech.2006.12. 002 .

Grotti, M., Soggia, F., Lagomarsino, C., Riva, S.D., Goessler, W., Francesconi, K.A., 2008 Natural variability and distribution of trace elements in marine organisms from Antarctic coastal environments. Antarct. Sci. 20, 39-52. http://dx.doi.org/10.1017/ S0954102007000831.

Hinrichs, J., Dellwig, O., Brumsack, H.-J., 2002. Lead in sediments and suspended particulate matter of the German Bight: natural versus anthropogenic origin. Appl. Geochem. 17, 621-632. http://dx.doi.org/10.1016/S0883-2927(01)00124-X.

Illuminati, S., Annibaldi, A., Truzzi, C., Scarponi, G., 2016. Heavy metal distribution in organic and siliceous marine sponge tissues measured by square wave anodic stripping voltammetry. Mar. Pollut. Bull. 111, 476-482. http://dx.doi.org/10.1016/j. marpolbul.2016.06.098.

Komárek, M., Ettler, V., Chrastný, V., Mihaljevič, M., 2008. Lead isotopes in environmental sciences: a review. Environ. Int. 34, 562-577. http://dx.doi.org/10.1016/j envint.2007.10.005.

Larsen, M.M., Blusztajn, J.S., Andersen, O., Dahllöf, I., 2012. Lead isotopes in marine surface sediments reveal historical use of leaded fuel. J. Environ. Monit. 14, 2893. http://dx.doi.org/10.1039/c2em30579h.

Li, X., Wai, O.W.H., Li, Y.S., Coles, B.J., Ramsey, M.H., Thornton, I., 2000. Heavy metal distribution in sediment profiles of the Pearl River estuary, South China. Appl. Geochem. 15, 567-581. http://dx.doi.org/10.1016/S0883-2927(99)00072-4.

Liu, L., Wang, Z., Ju, F., Zhang, T., 2015. Co-occurrence correlations of heavy metals in sediments revealed using network analysis. Chemosphere 119, 1305-1313. http://dx. doi.org/10.1016/j.chemosphere.2014.01.068.

Luoma, S.N., Rainbow, P.S., 2005. Why is metal bioaccumulation so variable? Biodynamics as a unifying concept. Environ. Sci. Technol. 39, 1921-1931. http://dx. doi.org/10.1021/es048947e.

Mahajan, N., Calabro, K., Morrow, C., Thomas, O., 2017. N-Didehydrotyrosine identified from the Northeastern Atlantic marine sponge Hymeniacidon perlevis after chemical screening. Nat. Prod. Commun. 12, 945-946.

Majer, A.P., Petti, M.A.V., Corbisier, T.N., Ribeiro, A.P., Theophilo, C.Y.S., Ferreira, P.A de L., Figueira, R.C.L., 2014. Bioaccumulation of potentially toxic trace elements in benthic organisms of Admiralty Bay (King George Island, Antarctica). Mar. Pollut. Bull. 79, 321-325. http://dx.doi.org/10.1016/j.marpolbul.2013.12.015.

Mancini, I., Guella, G., Frostin, M., Hnawia, E., Laurent, D., Debitus, C., Pietra, F., 2006 On the first polyarsenic organic compound from nature: arsenicin A from the new Caledonian marine sponge Echinochalina bargibanti. Chem. Eur. J. 12, 8989-8994. http://dx.doi.org/10.1002/chem.200600783.

Mayzel, B., Aizenberg, J., Ilan, M., 2014. The elemental composition of demospongiae from the Red Sea, Gulf of Aqaba. PLoS One 9. http://dx.doi.org/10.1371/journal. pone.0095775.

de Mestre, C., Maher, W., Roberts, D., Broad, A., Krikowa, F., Davis, A.R., 2012. Sponges as sentinels: patterns of spatial and intra-individual variation in trace metal concentration. Mar. Pollut. Bull. 64, 80-89. http://dx.doi.org/10.1016/j.marpolbul. 2011.10.020.

Milanese, M., Chelossi, E., Manconi, R., Sarà, A., Sidri, M., Pronzato, R., 2003. The marine sponge Chondrilla nucula Schmidt, 1862 as an elective candidate for bioremediation in integrated aquaculture. Biomol. Eng. 20, 363-368. http://dx.doi.org/10.1016/ S1389-0344(03)00052-2.

Monna, F., Ben Othman, D., Luck, J.M., 1995. Pb isotopes and Pb, Zn and Cd concentrations in the rivers feedinga coastal pond (Thau, southern France): constraints on the origin(s) and flux(es) of metals. Sci. Total Environ. 166, 19-34. http://dx.doi. org/10.1016/0048-9697(95)04514-2.

Müller, W.E.G., Batel, R., Lacorn, M., Steinhart, H., Simat, T., Lauenroth, S., Hassanein, H., Schröder, H.C., 1998. Accumulation of cadmium and zinc in the marine sponge Suberites domuncula and its potential consequences on single-strand breaks and on expression of heat-shock protein: a natural field study. Mar. Ecol. Prog. Ser. 167, 127-135. http://dx.doi.org/10.3354/meps167127.

Negri, A., Burns, K., Boyle, S., Brinkman, D., Webster, N., 2006. Contamination in sediments, bivalves and sponges of McMurdo Sound, Antarctica. Environ. Pollut. 143, 456-467. http://dx.doi.org/10.1016/j.envpol.2005.12.005.

Olesen, T.M.E., Weeks, J.M., 1994. Accumulation of Cd by the marine sponge Halichondria panicea pallas: effects upon filtration rate and its relevance for biomonitoring. Bull. Environ. Contam. Toxicol. 52, 722-728. http://dx.doi.org/10.1007/ BF00195494.

Orani, A.M., Barats, A., Zitte, W., Morrow, C., Thomas, O.P., 2018. Comparative study on the bioaccumulation and biotransformation of arsenic by some northeastern Atlantic and northwestern Mediterranean sponges. Chemosphere 201, 826-839. http://dx. doi.org/10.1016/j.chemosphere.2018.03.078.

Ortega, G.S., Pécheyran, C., Bérail, S., Donard, O.F.X., 2012. A fit-for purpose procedure for lead isotopic ratio determination in crude oil, asphaltene and kerogen samples by MC-ICPMS. J. Anal. At. Spectrom. 27, 1447. http://dx.doi.org/10.1039/c2ja30143a.

Ostrom, K.M., Simpson, T.L., 1978. Calcium and the release from dormancy of freshwater sponge gemmules. Dev. Biol. 64, 332-338. http://dx.doi.org/10.1016/0012 1606(78)90083-0.

Padovan, A., Munksgaard, N., Alvarez, B., McGuinness, K., Parry, D., Gibb, K., 2012. 
Trace metal concentrations in the tropical sponge Spheciospongia vagabunda at a sewage outfall: synchrotron X-ray imaging reveals the micron-scale distribution of accumulated metals. Hydrobiologia 687, 275-288. http://dx.doi.org/10.1007/ s10750-011-0916-9.

Pan, K., Lee, O.O., Qian, P.Y., Wang, W.X., 2011. Sponges and sediments as monitoring tools of metal contamination in the eastern coast of the Red Sea, Saudi Arabia. Mar. Pollut. Bull. 62, 1140-1146. http://dx.doi.org/10.1016/j.marpolbul.2011.02.043.

Parra, S., Bravo, M.A., Quiroz, W., Querol, X., Paipa, C., 2015. Distribution and pollution assessment of trace elements in marine sediments in the Quintero Bay (Chile). Mar. Pollut. Bull. 99, 256-263. http://dx.doi.org/10.1016/j.marpolbul.2015.07.066.

Patel, B., Balani, M., Patel, S., 1985. Sponge "sentinel" of heavy metals. Sci. Total Environ. 41, 143-152.

Perez, T., Vacelet, J., Rebouillon, P., 2004. In situ comparative study of several Mediterranean sponges as potential biomonitors for heavy metals. Boll. Mus. Ist. Biol. Univ. Genova 68, 517-525.

Perez, T., Longet, D., Schembri, T., Rebouillon, P., Vacelet, J., 2005. Effects of 12 years' operation of a sewage treatment plant on trace metal occurrence within a Mediterranean commercial sponge (Spongia officinalis, Demospongiae). Mar. Pollut. Bull. 50, 301-309. http://dx.doi.org/10.1016/j.marpolbul.2004.11.001.

Phillips, D., Rainbow, P., 1988. Barnacles and mussels as biomonitors of trace elements: a comparative study. Mar. Ecol. Prog. Ser. 49, 83-93. http://dx.doi.org/10.3354/ meps049083.

Pronzato, R., 2004. A climber sponge. Boll. Mus. Ist. Biol. Univ. Genova 68, 549-552.

Rainbow, P., 2002. Trace metal concentrations in aquatic invertebrates: why and so what? Environ. Pollut. 120, 497-507. http://dx.doi.org/10.1016/S0269-7491(02) 00238-5.

Rand, G.M., Wells, P.G., McCarthy, L.S., 1995. Introduction to aquatic ecology. In: Rand, G.M. (Ed.), Fundamentals of Aquatic Toxicology. Taylor and Francis, London, pp. $3-53$.

Sjåstad, K.-E., Simonsen, S.L., Andersen, T., 2011. Use of lead isotopic ratios to discriminate glass samples in forensic science. J. Anal. At. Spectrom. 26, 325. http://dx. doi.org/10.1039/c0ja00054j.

Søndergaard, J., Asmund, G., Larsen, M.M., 2015. Trace elements determination in seawater by ICP-MS with on-line pre-concentration on a Chelex-100 column using a "standard" instrument setup. MethodsX 2, 323-330. http://dx.doi.org/10.1016/j mex.2015.06.003.

Split, P.M., Delta, A., 2010. Sediment Quality Guidelines for the Protection of Aquatic Life. Canadian Council of Ministers of the Environment.
Tompkins-MacDonald, G.J., Gallin, W.J., Sakarya, O., Degnan, B., Leys, S.P., Boland, L.M., 2009. Expression of a poriferan potassium channel: insights into the evolution of ion channels in metazoans. J. Exp. Biol. 212, 761-767. http://dx.doi.org/10.1242/ jeb.026971.

US EPA, 2006. Marine Sediment Screening Benchmarks. III, Region.

Vacelet, J., Donadey, C., 1977. Electron microscope study of the association between some sponges and bacteria. J. Exp. Mar. Biol. Ecol. 30, 301-314. http://dx.doi.org/ 10.1016/0022-0981(77)90038-7.

Vanhaecke, F., Degryse, P., 2012. The isotopic composition of the elements. In: Isotopic Analysis: Fundamentals and Applications Using ICP-MS. John Wiley and Sons, pp. 1-29. http://dx.doi.org/10.1002/9783527650484.

Vanhaecke, F., Balcaen, L., Malinovsky, D., 2009. Use of single-collector and multi-collector ICP-mass spectrometry for isotopic analysis. J. Anal. At. Spectrom. 24, 863. http://dx.doi.org/10.1039/b903887f.

Varol, M., 2011. Assessment of heavy metal contamination in sediments of the Tigris River (Turkey) using pollution indices and multivariate statistical techniques. J. Hazard. Mater. 195, 355-364. http://dx.doi.org/10.1016/j.jhazmat.2011.08.051.

Venkateswara Rao, J., Srikanth, K., Pallela, R., Gnaneshwar Rao, T., 2009. The use of marine sponge, Haliclona tenuiramosa as bioindicator to monitor heavy metal pollution in the coasts of Gulf of Mannar, India. Environ. Monit. Assess. 156, 451-459. http://dx.doi.org/10.1007/s10661-008-0497-x.

Véron, A., Flament, P., Bertho, M.L., Alleman, L., Flegal, R., Hamelin, B., 1999. Isotopic evidence of pollutant lead sources in northwestern France. Atmos. Environ. 33, 3377-3388. http://dx.doi.org/10.1016/S1352-2310(98)00376-8.

Weis, P., Weis, J.S., 1999. Accumulation of metals in consumers associated with chromated copper arsenate-treated wood panels. Mar. Environ. Res. 48, 73-81. http://dx doi.org/10.1016/S0141-1136(99)00028-8.

Weng, N., Wang, W.X., 2014. Variations of trace metals in two estuarine environments with contrasting pollution histories. Sci. Total Environ. 485-486, 604-614. http://dx. doi.org/10.1016/j.scitotenv.2014.03.110.

Yamaoka, Y., Carmona, M.L., Oclarit, J.M., Jin, K., Shibata, Y., 2001. Arsenic compounds in marine sponge (Haliclona permolis, Halichondria japonica, Halichondria okadai and Haliclona sp. white) from Seto Inland Sea, Japan. Appl. Organomet. Chem. 15, 261-265. http://dx.doi.org/10.1002/aoc.135.

Yamaoka, Y., Carmona, M.L., Oclarit, J.M., Jin, K., Shibata, Y., 2006. Characterization of water-soluble organoarsenic compounds in marine sponges. Appl. Organomet. Chem. 20, 545-548. http://dx.doi.org/10.1002/aoc. 